\title{
الولاء في الميراث (دراسة تحليلية من تحقيق كتاب الفرائض للشافعي -نموذجا-) 1
}

\section{| (ل)}

الولاء فالإرث به ثابت بالإجالع. وبأنه صلى الله عليه وسلم : كورث بنت حمز رضي الله عنه من

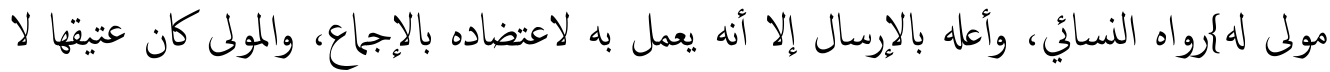

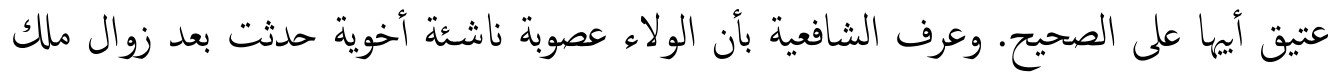

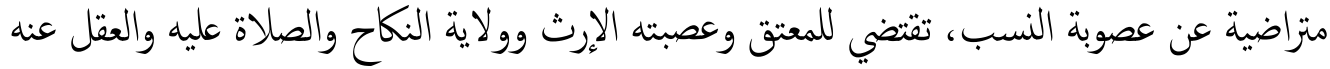
.ويقسم الولاء إلى أنواع ثلاثة: وهولاء العتاقة أو النعمة، وهو عصوبة سبيها نعمة المعتق على رقيق

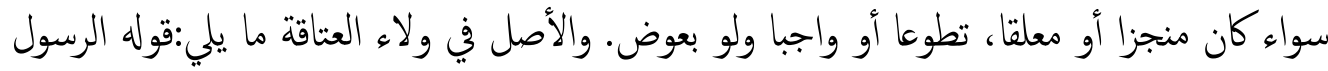

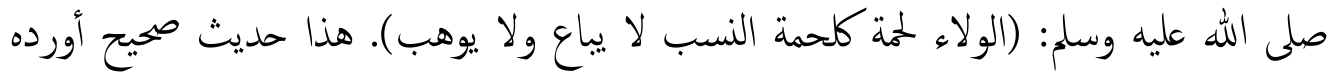

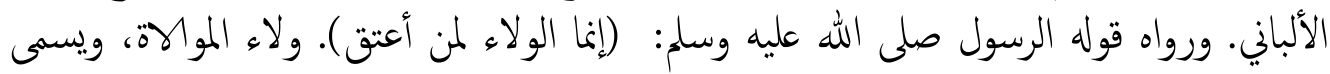
ولاء المناصرة: وصورته هي أن يعقد شخص مع آخر ليس له أقارب عقد محالفة كأن يقول له: "أنت مولاي ترثني إذا مت، وتعقل عني إذا جنيت". و لاء الإمامة: فقد ذهب إلى الإرث بولاء الإمامة

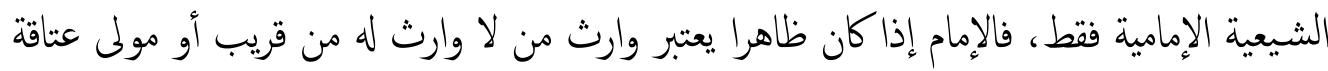
أو مولى موالاة.

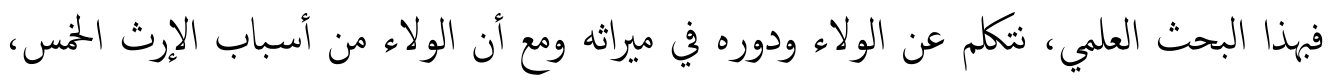

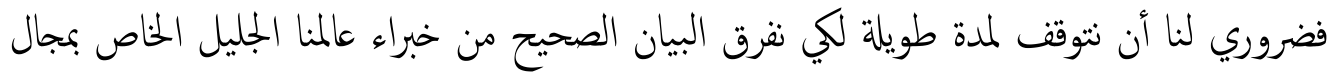
هذا العلم الدقيق مع البيان الذي ينتشر ويجري في دور حياة مجتمعنا الحاضر.

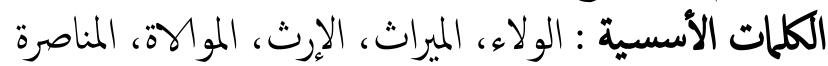

\begin{abstract}
Abstrak
Naskah ulama yang dikaji dalam artikel ini adalah karya Imam Syafii yang berjudul al-Wala' fi al-Mirats (Kedudukan Wali dalam Hukum Waris). Tulisan ini akan mengkaji naskah dari segi kandungan isi. Selain itu, naskah juga dijelaskan menggunakan sumber-sumber lain dari pandangan ulama dari mazhab yang berbeda yang tentu saja dikaitkan dengan berbagai dalil yang menjadi dasar argumentasinya. Dari hasil kajian diperoleh beberapa poin penting, yaitu bahwa seorang wali berhak mendapatkan waris dari orang yang diwalkannya berdasarkan Hadis Rasulullah Saw dan ijmak ulama. Wali yang berhak mendapatkan warisan ada tiga macam, yaitu wali atas budak (wala' al-'ataqah) sehingga ia mewarisi dari budaknya, wali penolong (wala' al-muwalah/munashirah) sehingga ia mewarisi dari orang ada hubungan persahabatan/perjanjian, dan wali pemerintah (wala' al-imamah) sehingga mewarisi orang yang tidak memiliki pewaris.
\end{abstract}

Kata kunci: wala', mirats, irts, muwalah, munashirah

\footnotetext{
${ }^{1}$ Universitas Al-Azhar Indonesia , Email : iin.suryaningsih@uai.ac.id
} 
العلمية بداية في درجة التخصص مقدمة

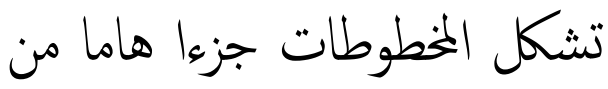

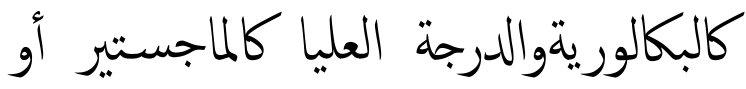
التراث الذي أبدعته الحضارة العربية الدكتوراه من خلال تحقيق المخطوطات والإسلامية في حقول كثيرة المعرفة الإنة ونشرها، وهذا لا يقل أهية عن كنابة

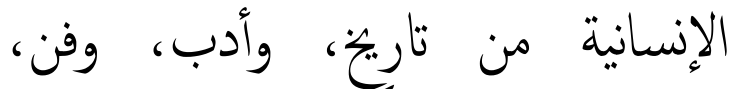
وفلك، وطب، وويمياء وكذلك سائر بحث إبداعي جديد.

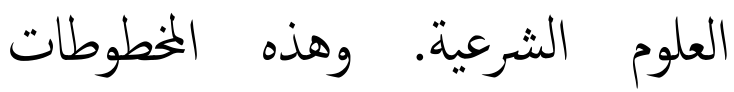
بالعربية (قليلة باللغة الفارسية والتركية)

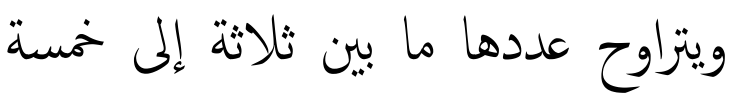
ملايين خخطوط، موزعة في مكتبات العالم

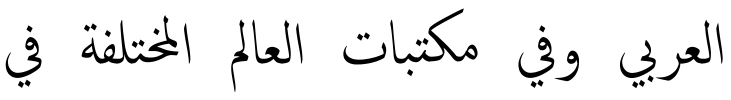
أوربا وأمريكا وبعض دول آسيا ولاسيا

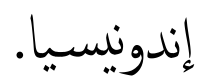

ظلت هذه الخمطوطات، مثلها مثل سائر أنواع تراثنا محملة ومنسية، ولم المطات

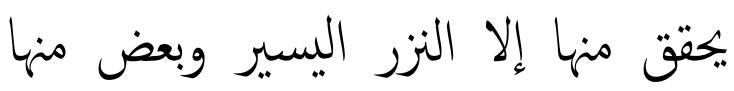
أعيد تحقيقه وطبعه عدة مرات إما لأهميته

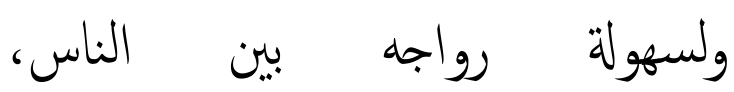
فالمستشرقون قد بدؤوا بحصة كيرة مما نشر من تلك المخطوطات. واهتمت من الجامعات والجامعات الأخري فيدول أسيا بتشجيع

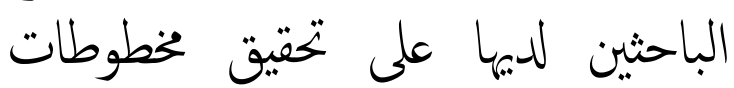
تتعلق باختصاصهم كجزء من أطروحاتهم العلمية فأجازت الحصول على الدرجات

\section{المواريث والحكة التشريعية في اختلاف مقاديرها}

(2) تحقيق المخطوطات بين النظرية

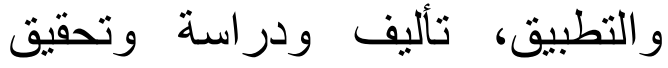
الدكتور فهمي سعد و الدكتور طلال مجذوب ص 4-5، مطبعة عالم الكتب

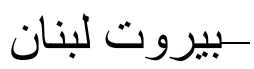


لقد وضعت الثريعة الإسلامية

نظام التوريث على أحسن النظم المالية،

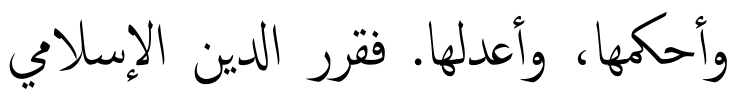

ملكية الإنسان للمال ذكرا كان أو أنى الثرلي

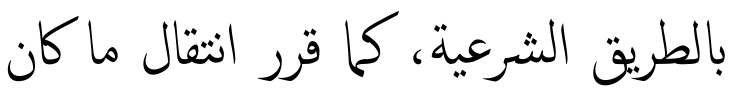

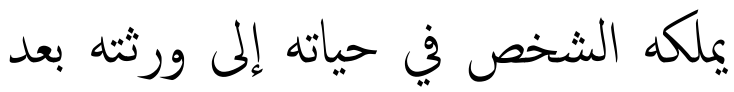

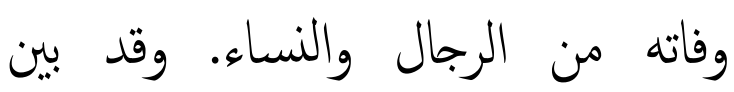

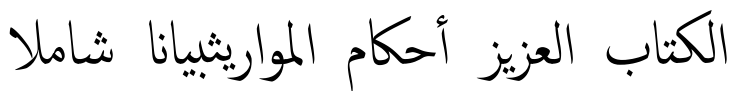
شافيا، فالقرآن الكريم هو العُمدة في المواريطان أحكامها ومقاديرها.

قال عبد الله بن مسعود-رضي الله عنه- : (من قرأ منكم القرآن فليتعلم

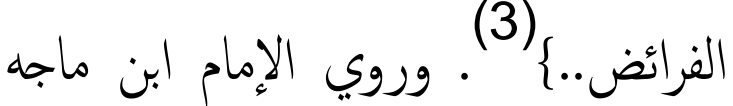
في سننه، عن أبي هريرة-رضي الله عنه-

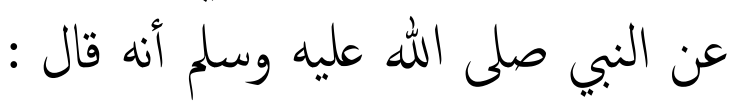
\}تعلموا الفرائض وعلموها، فإنه نصف النف النه العلم وهو ينسى وهو أول شيء ينزع من النهان

$$
\text { أمتي\{ (4) }
$$

وقد توالت ججود العلماء على بيان هذا العلم وإبرازه، وبيان حكم ما استجد

(3)|المستدرك الإمام الحاكم، كتاب الفر ائض باب تعليم الفرائض، 370/4

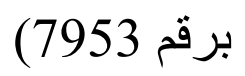

(4)سنن ابن ماجه، كتاب الفر ائض باب الحث على تعليم الفرائض النه
من مسائل، فصنفوا المصنفات الكثيرة التي مازال أكثرها في خزائن المخطوطات في مكتبات العالم، ومن هذه المصنفات الكثيرة : (كتاب منهج الوصول إلى تحرير

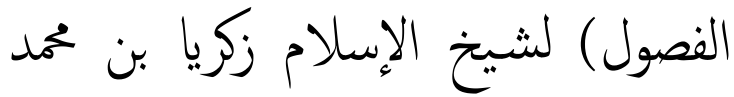

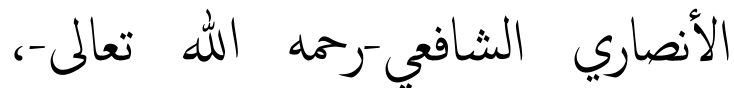

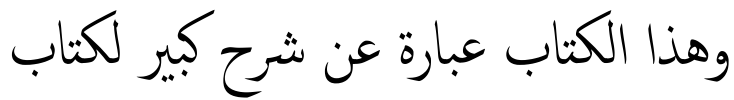
الفصول المهمة في مواريث الأمة للإمام أحمد بن الهائم الفرضي الشافعي رحمه الله تعالى

ولقد كان الجاهليون لا يورثون

الأطفال ولا النساء بحجة أن الأطفال

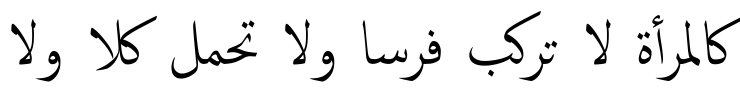
تُنكي عدوا ولا تدافع عن حمى العشيرة.

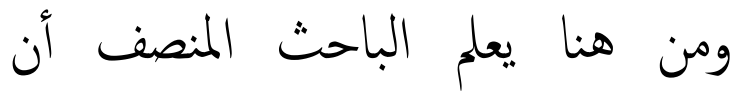

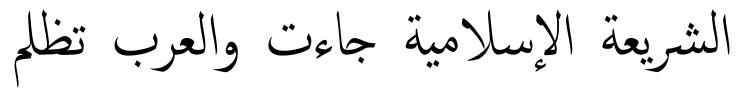
النساء، ولا تعطيهن من ميراث أزواجهن

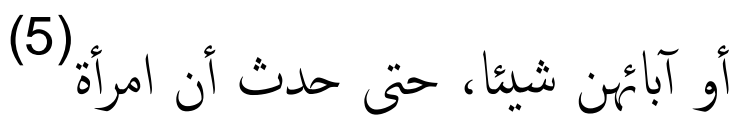

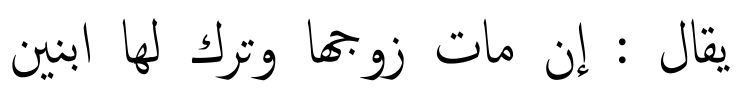

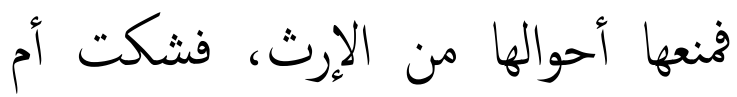
كجة إلى رسول الله صلى الله عليه

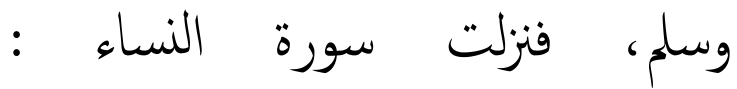

رواه أبو داود في سنته، كتاب الفرائض باب ما جاء في الصي الصلب،

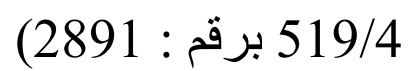




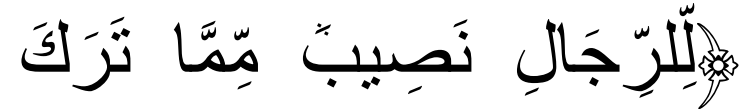

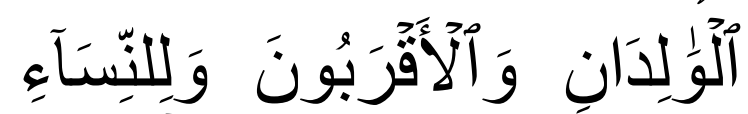

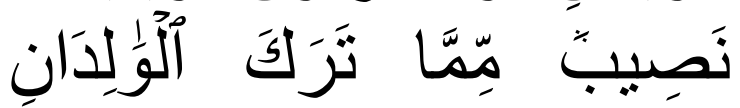

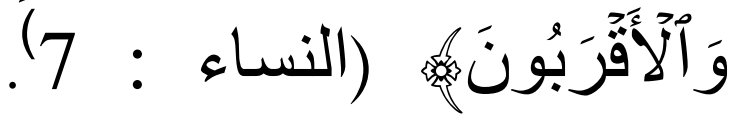
وبهذا جاء الدين الإسلامي بالعدالة، وهذه النظرية الإسلامية المتمشية مع العطف العنف

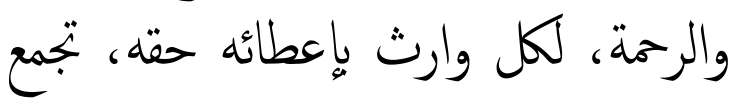

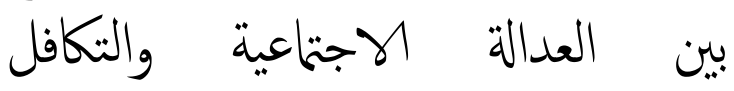
الاجتاعي بين أفراد الأسرة الواحدة التي يربطها أسباب الإرث من قرابة بنسب أو الو الوادي بسب.

قال شيخ الإسلام زكريا الأنصاري-رمها الله تعلى - في كتاب نهاية

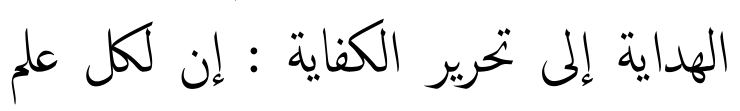

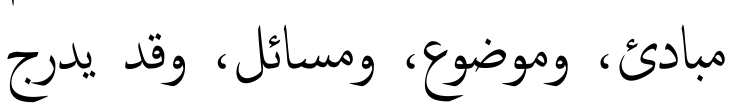

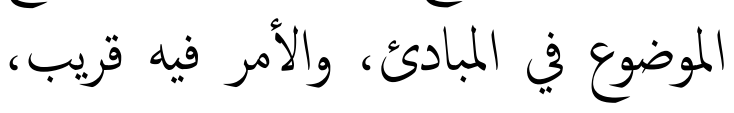
ومبادئه هي الأشياء التي تبنى عليها

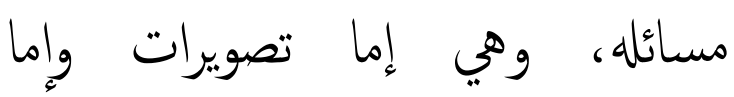
تصديقات.فالتصويرات : هو ما يستعمل فيه كفايته. والتصديقات : مقدمات تؤولن التهات منها قياسات العلم وهي إما بينة بنفسها

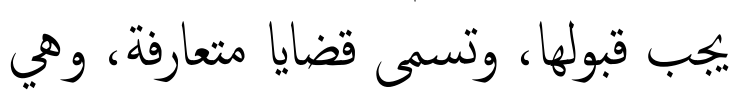
المبادىء على الإطلاق، لأنها ليست إنست مسائل بالنسبة إلى علم آخر، أو في ذلك الأك
العلم لكن بشرط : أن لا يدور البيان، وذلك بأن تبين بمسائل غير متوققة عليها، لإن المبان وهي مباديء بالقياس إلى العلم المبني عليها، ومسائل بالقياس إلى العلم الآخر ، الماني

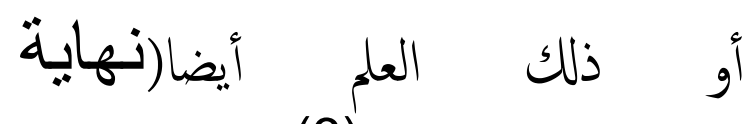

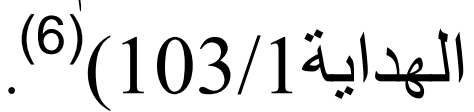
كل ما كتبه العلماء في القديم والحديث، وكل ما ألفوه في علم المواريث

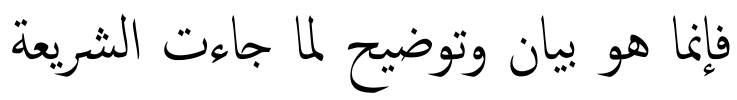

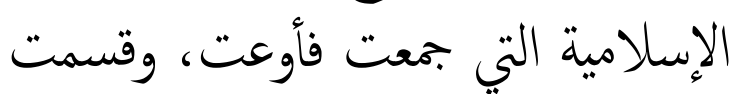

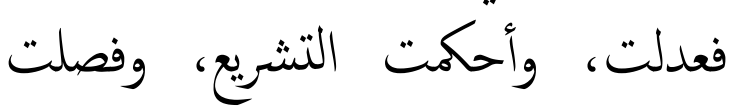

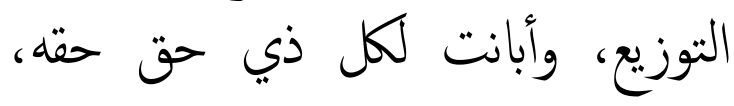
دون محاباة أو مداراة، فالله شيع الأحكام

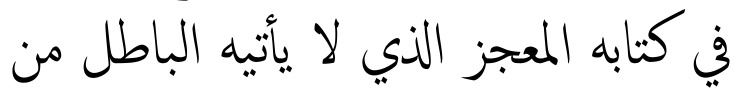

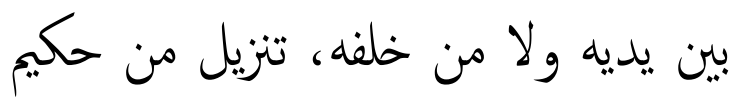
حميد، وجلت حكمة الله وتشريعه الكامل

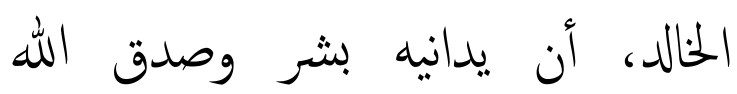

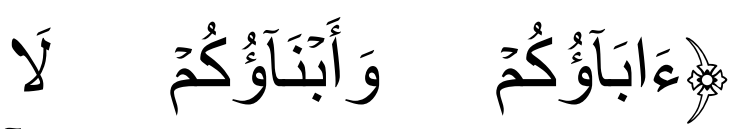

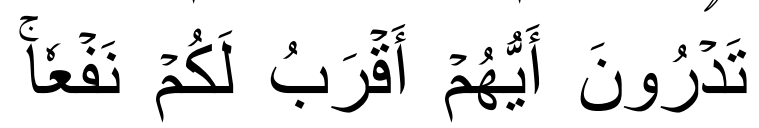

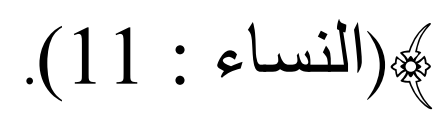

(6)نهايـة الهايـة إلـى تحريـر الكفايـة،

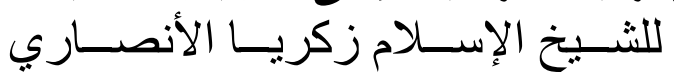
103/1 
وقد شرع الله المواريث وبينها بكتابه وبلغها رسوله إلى أمته، كما فهمها

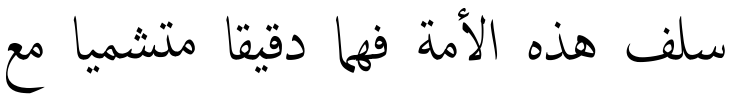

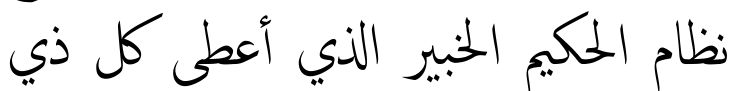
حق حقه، فكما قرر ملكية الإنسان للمال قرر انتقاله لمستحقه بعد الموت مالمكان إلى المالى الورثة الذين هم أولى بهذا الحق، كما أن المبن

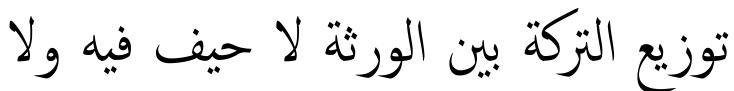
شطط، كما بين أيضا الحقوق المتعلقة الإنة

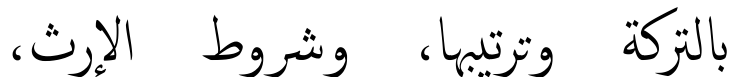

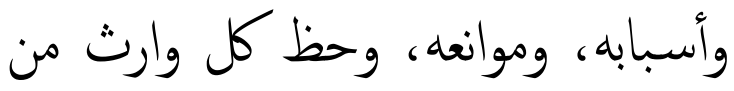
التركة، وبهذا تمت العدالة وأزيلت أسباب من وارث

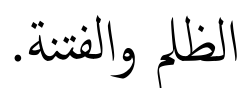

قد تساءل البضض لماذا أعطيت المرأة نصف الرجل مع أنه أضعف منه الماته وأحوج للمال؟ والجواب هو أن الشريعة ألمان

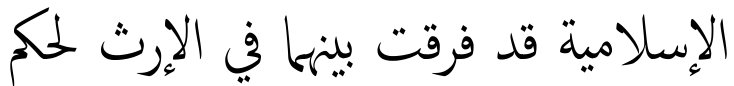
كثيرة، ذكر بعض العلماء منها:أولا : أن الن

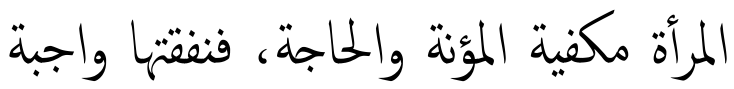
على ابنها أو أبيها، أو أخيها، أو زوبجا أو أو المانية

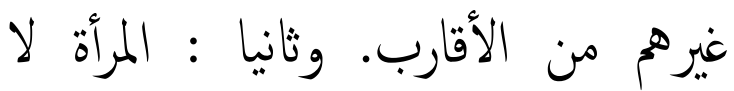
كلكف بالإنفاق على أحد، بخلاف الرجل

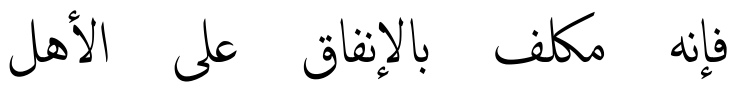

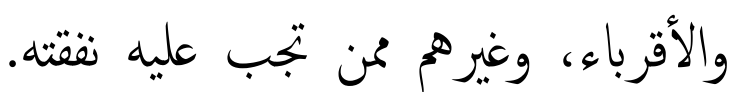
وثالثا : نفقات الرجل أكثز والتزاماته المالية
أضخم، فاجته إلى المال أكبر من حاجة

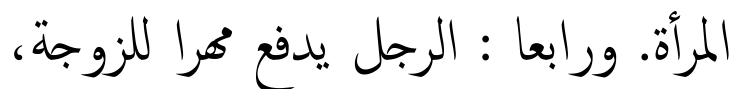

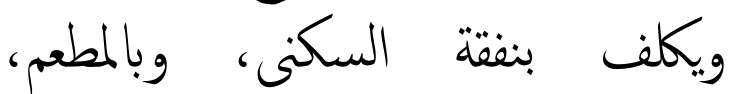

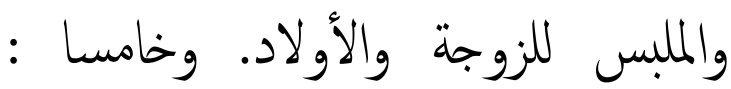

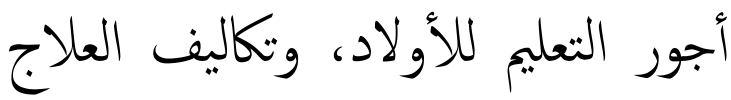
والدواء للزوجة والأبناء يدفعها الرجل لالداجل دون المرأة.

إلى آخر ما هنالك من المصاريف والنققات التي هي على كاهل الرجل،

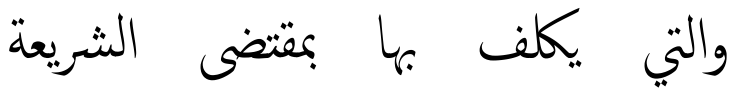

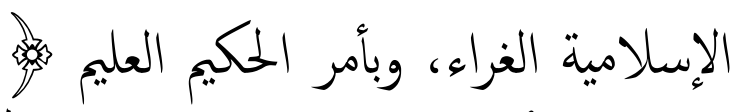

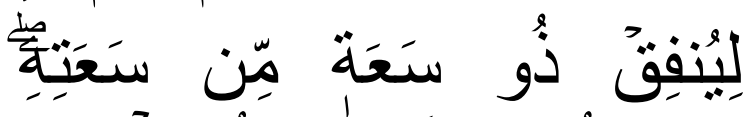

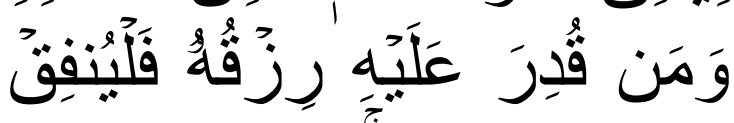

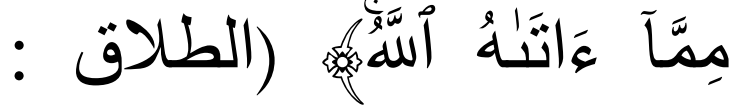

ومع أن الإسلام أعطى الذكر ضعف الأنىى، فإنه مع ذلك الإنلام نعر المرأة

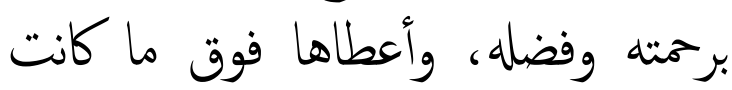

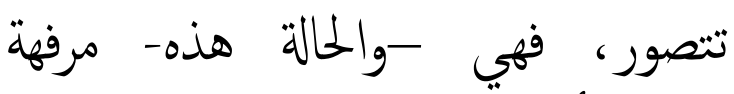
ومنعمة أكثر من الرجل، لأنها تشاركه في

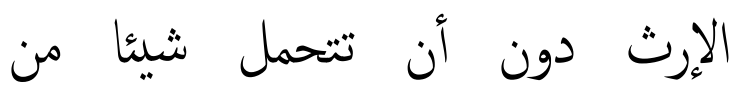
التبعات، فهي تأخذ ولا تعطى، وتنغم ولان تغرم، وتدخر دون تدفع شيئا من لالات 
النفقات، أو تشارك الرجل في تكاليف العيش ومتطلبات الحياة.

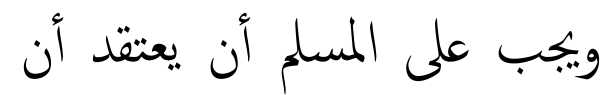

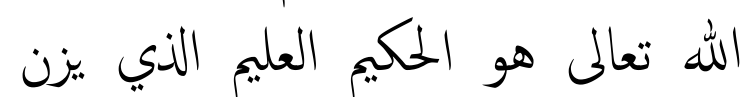
الأمور بميزان العمل، وأنه هو الأعلم بما لمانم

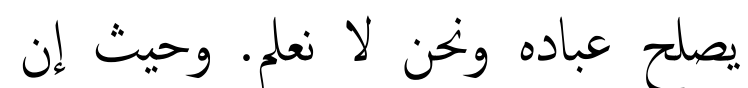
المصلحة في العبادات البدنية والمصلحة في الماتي

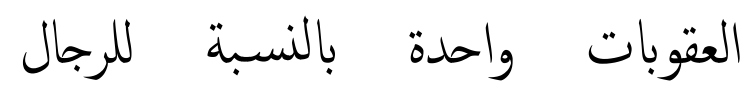

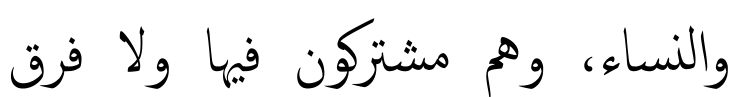

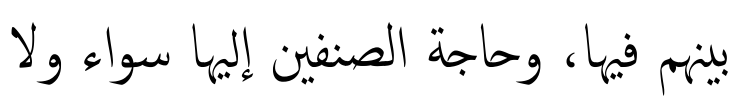

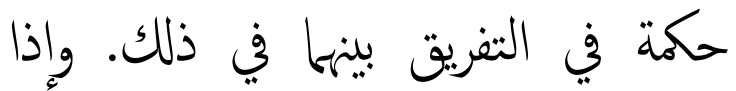
تفهمنا ذلك بعد هذه الإشارة نرى أن التفرقة في الميراث حكمتها ظاهرة جليةوالله المستعان.

عالمنا الجليل الفرضي الشافعي ومكانه العلمية

هو زكريا بن محمد بن أحمد بن الأن المية

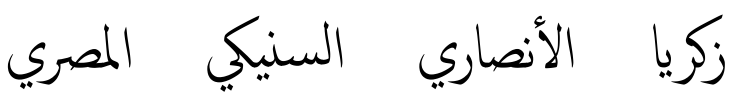

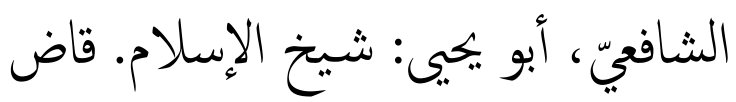

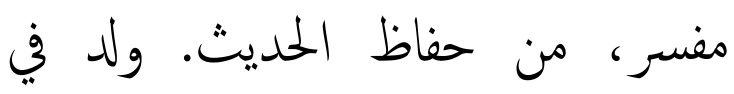
سنيكة (بشرقية مصر) وتعلم في القاهرة وكف بصره سنة 906 هـ نشأ فقيرا معدما. ولد سنة 826هـ فِفظ الْقُرَّن وعمدة الأحكام وَبَض مُخْتَصر التبريزي
في الْفِقهه تََّّ تحوّله الأول إلى الْقَاهرَة فِي

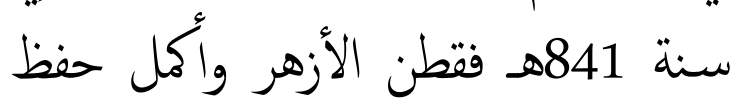

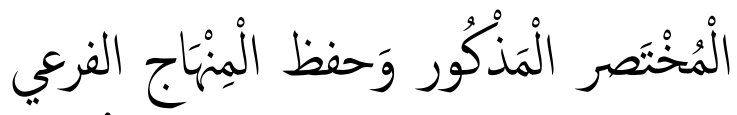

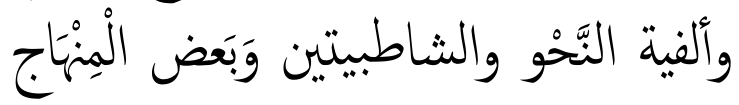

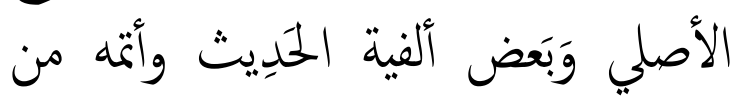

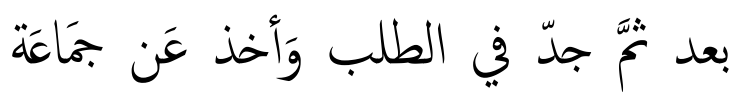
هِنُْم : البلقيني، والقاياتي، والثرف

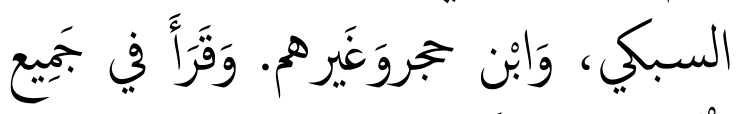
الْفُُون وَأذن لَهُ شُيُوخه بالإفتناء.

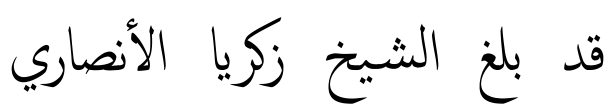

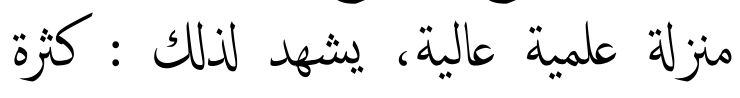

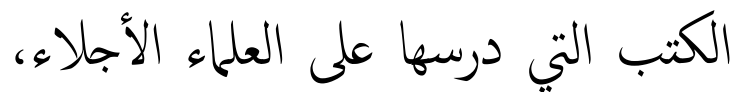
حيث قرأ وسمع أكثر من مائة كتاب في الكي الكي الفقه وأصوله، والسنة وعلومها، واللغة من مائه

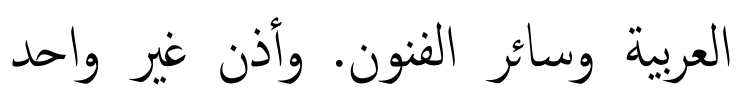
من العلماء -من مشايخه- له بالإقتناء والإقراء كأمثال شيخ الإسلام ابن حجر

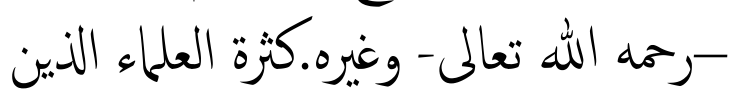

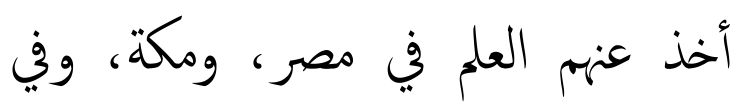
غيرها من بلاد المسلمين، وكثرة العلماء

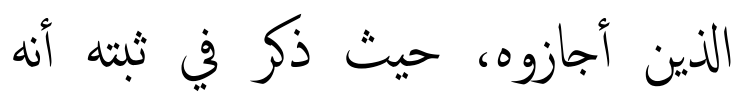
أجازه كثير من العلماء. وكثرة المؤلفات العلمية التي قام بتأليفها في سائر العلوم، العاه

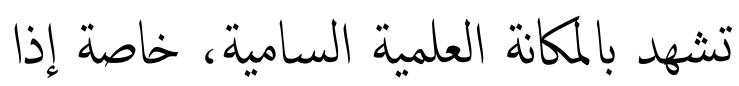
علمنا أن كثيرا من مؤلفات الشيخ زكريا 
قد انتشرت في الآفاق، وأخذ كثير من أهل العلم بدراستها -رحمه الله تعالى - فئل

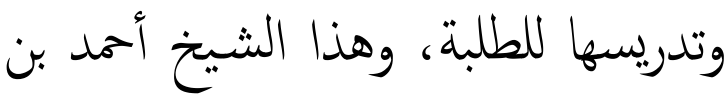
حسن بن رشيد الحنبلي -رحمه الله تعالى-، يدرس ((شرح الجزرية)) للشيخ

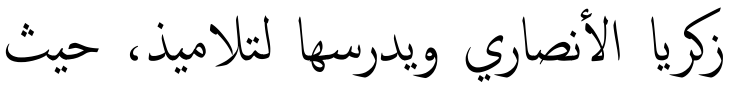

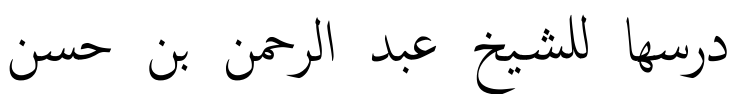
صاحب كناب ((قرة عيون الموحدين في كني

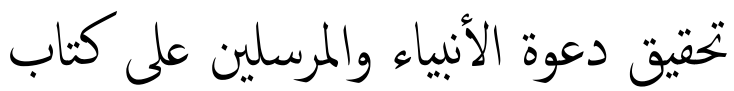
التوحيد)). وتصدى للإفتاء في حياة شيوخه وانتفاع الفضلاء به طبقة بعد النهاء

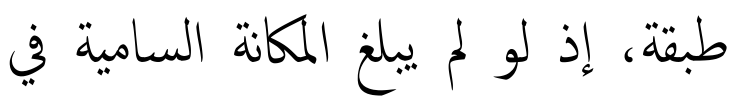

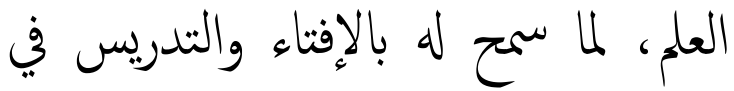

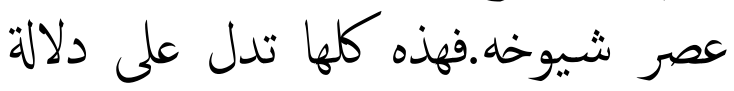
واضحة على أن الشيخ زكريا الأنصاري ذو مكانة علمية رفيعة بين أهل العلم. فن الضروري في كلامنا هذا،

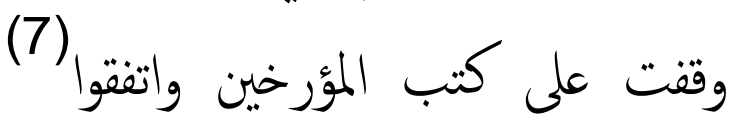
على أن وفاة الشيخ زكريا الأنصاري - لئ لمورخين

(7)شــرات الـذهب لابن العهـاد 135/8،

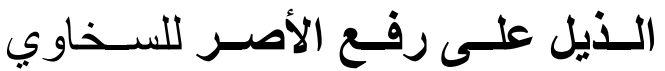

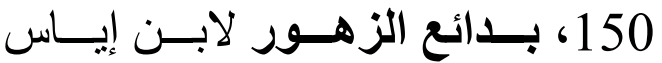

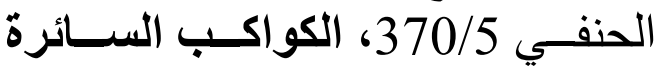

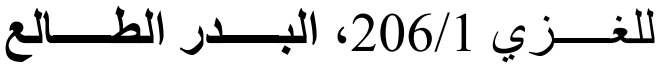

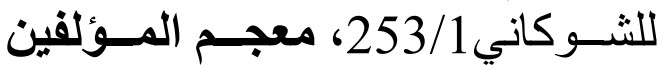
$.182 / 4$
رحمه الله- كانت عام 926هـ إلا أنهم اختلفوا في اليوم والشهر الذي توفي فيه (8) من تلك السنة :مثل ابن العهاد (8) في شذرات الذهب قال : إنه توفي يوم الجمعة اين العن رابع ذي الحجة. وقال ابن إياس (9) في بدائع الزهور : إنه توفي يوم الأربعاء ثالث إنا

شهر ذي الحجة. ومنهم (10) من قال : إنه توفي يوم الأربعاء ثالث شهر ذي القهن القعدة. أما السخاوي (11) فقال : ورد الخبر إلى نه دمشق أنه توفي في شهر ذي الحجة - فال

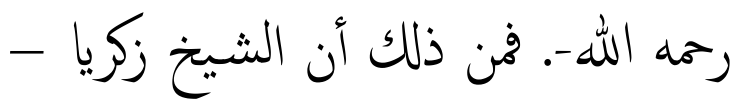

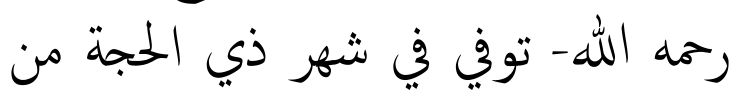
سنة 926هـ، والله أعلم. توفي فئ

\section{الولاء :دوره وأوجه المختلفة في الميراث}

الوَلاء أيالقرابة هو عصوبة سبيها

العتق. وسمي ذلك ولاء لانتساب العتيق

(8) ابن العهاد في كتابـه شـذرات الذهب

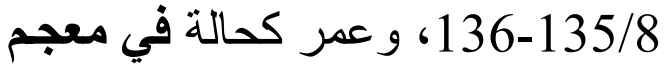

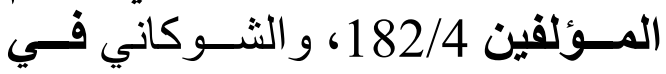

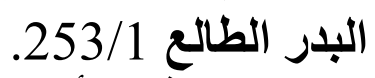

(9) ابن إيـاس في تأريخهـ بـائع الزهور 370/5

(10) الغزي في كتابه الكواكب السيائرة .206/1 (11)(السخاوي في الذيل على رفع الأصر 150 
إلى معتقه كانتساب الولد إلى والده، والأصل فيه قبل الإجحاع. قوله صلى الله (12)

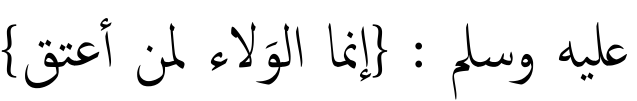

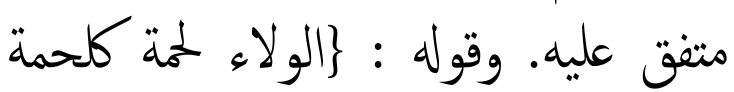

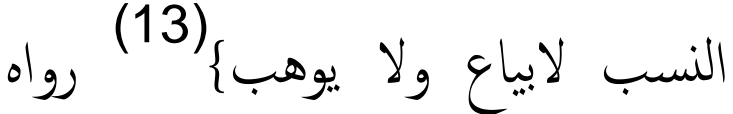

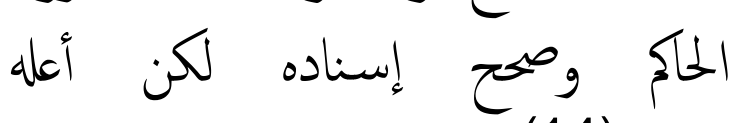
البيهتي (14)

ويعلم أن الولاء لا بياع ولا يوهب أنه لا ينتقل عن مستحقه كالنسب، فلو أعتق عبدا على أن لا ولاء له عليه عليه أو فلو

(12)راجع : الجامع الصحيح للإمام

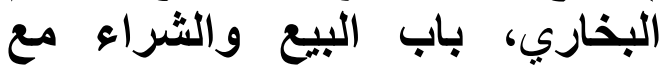

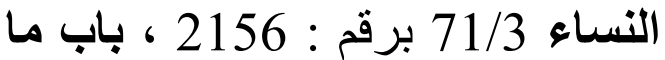
يجوز من شروط المكاتب وباب استعانة المكاتب وسؤاله 152/3 برقاتب

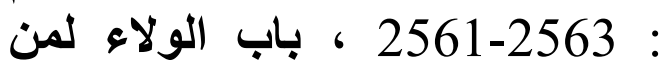
أعتق وميراثه 154/8 15753 برقاب الولاء لـن 6752)،والجامع الصحيح للإمام مسلم،باب إنما الولاء لمن أعتق لوالمام

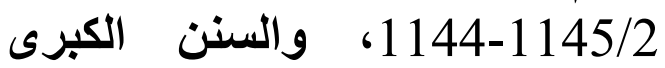
للإمام البيهقي، 551/5 برقم : 10845

(13) الحاكم في مستدركه،كتاب الفرائض

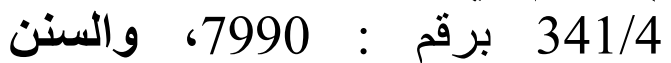

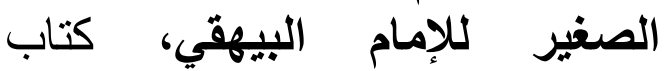
الفرائض باب الولاء).210/4 برقم : 3435

(14) رواه الإمام البيهقي في السنن الكبرى، كتاب الفر ائضباب الميراث بالو لاء 394/6 برقم : 12381
على أن يسيبه لفي الثرط وثبت الولاء

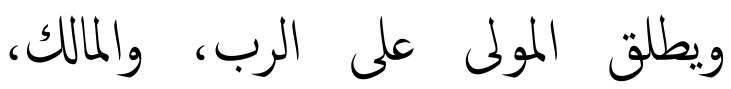

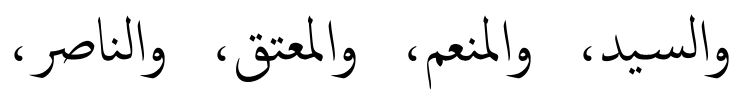

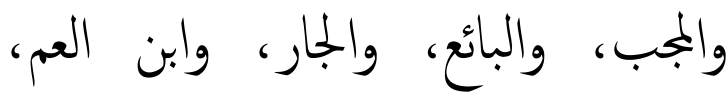
والحليف، والعقيد، والصهر، والعبد، والئ، والئ، والين، والمنعم عليه، والعتيق. والأحق بالإرث بسبب العبت العصوبة بعد فقد عصوبة النسب المعتق ذكراكان

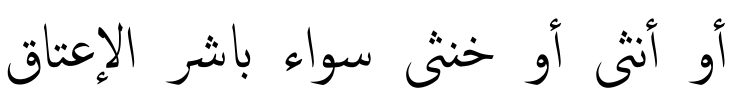

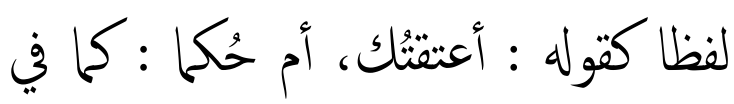
عتق بعضه عليه بدخوله في ملكه وسواء كان منجزا أم معلقا بعوض كالكنابة أح لاه بلا،

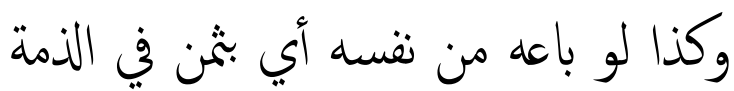
على الأصح أو أعتقه عن غيره بغير إذنه لئه

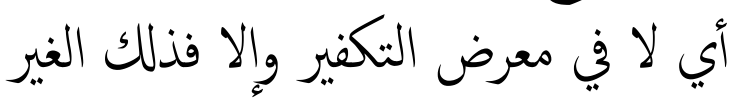
هو الحق.

وظاهر كلامه أو لأن المعتق إنما

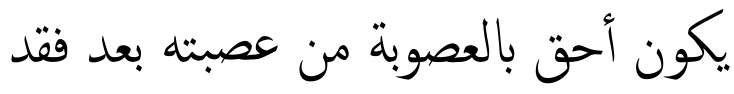
عصوبة النسب وليس كذلك، بل هو هو أحق بها قبل الفقد أيضا لكن تأثيرها إنما يكون بعد الفقد فليحمل كلامه بقرينة

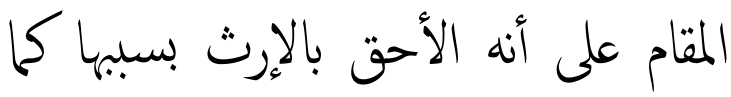

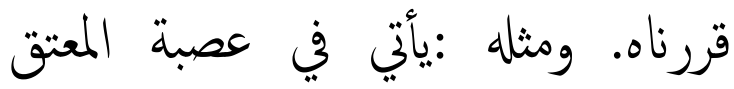
ومعتقه وأراد بالمباشر من وقع عنه العتق فئن

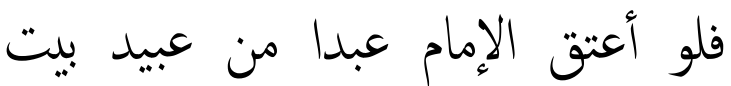


المال ثبت الولاء عليه للمسلمين مباثرة

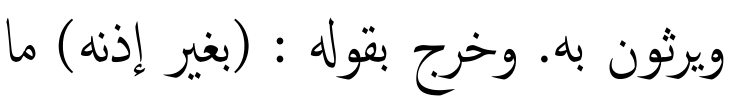

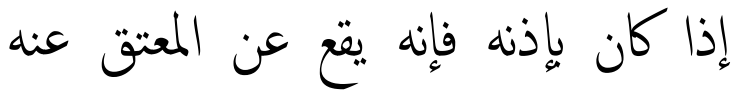
لوجود الإذن ومحل ما تقرر إذا لم يطرأ

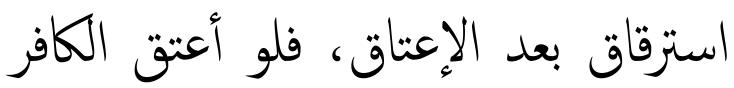

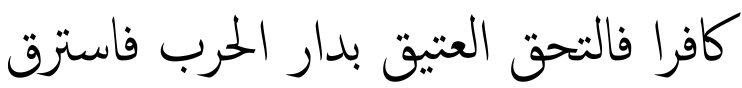
ثم أعتقه السيد الثناني.

فقيل : ولاؤه للسيد الأول

الاستقراره له أولا، وقيل : للثاني لأن

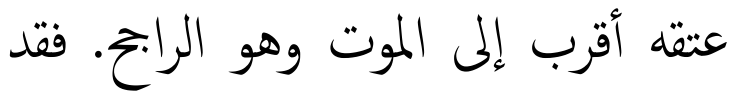

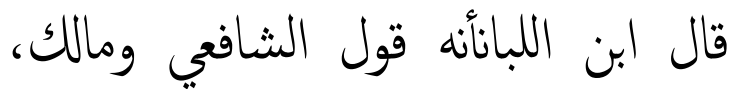

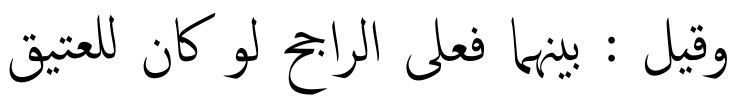

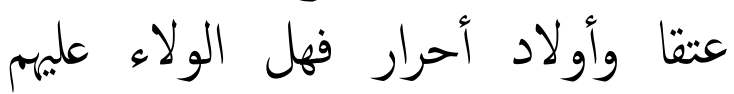
للأول أو ينجر الثاني لماد أر لاعتئاء فلاء فيه كلاما.

ورأيت في بعض كنب الحنابلة أنه ينجر لأنه أثرا لعتق الأول وقد زال فيزول

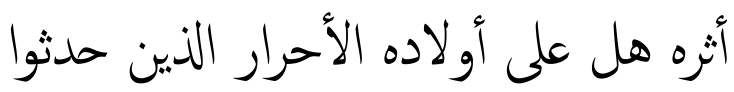

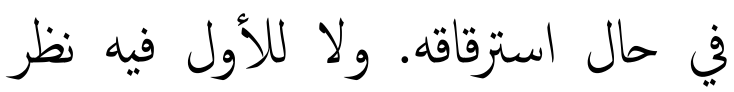
والأقرب أن يقال إن كانوا من عتيقة،

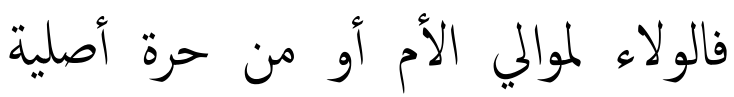

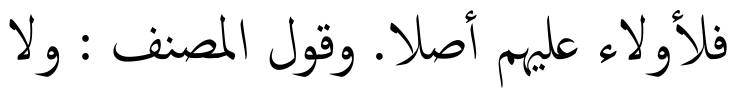

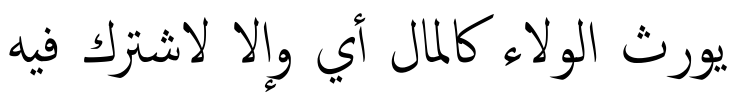
الرجال والنساء ولتوارث به الزوجان وهاء باطلان بل هو كالنسب يورث به به ولان وهان
يورث. ولهذا لا يمنع ثبوته اختلاف الدين

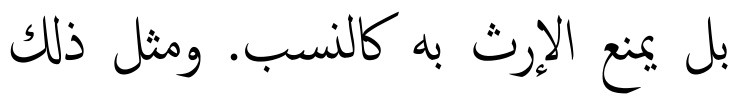
اختلاف الداركما إذا أعتق الذي حربيا.

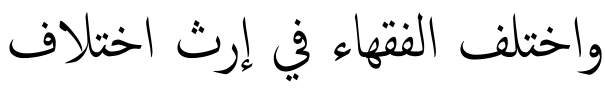
الدارين حقيقة لغير المسلمين (أي: الذي إنيا

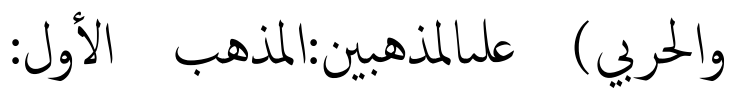
المالكية والحنابلة والشافعية في قول لهم. قالوا: اختلاف الدارين غير مانع للإرث

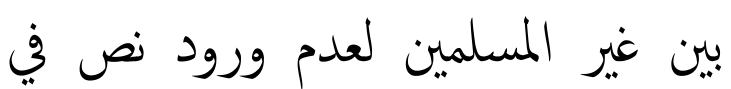
ذلك، وكذلك لعموم قوله تعالى:

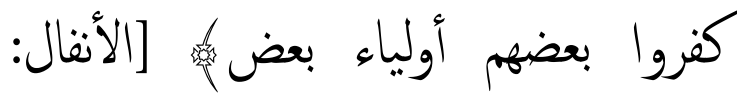

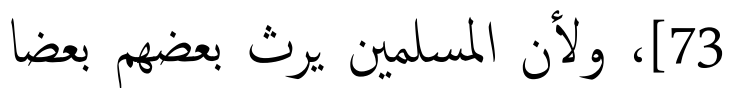
مع اختلاف الدار، فكذلك الكفار.(المغني 204/6).المذهب الثاني: مذهب الحنفية

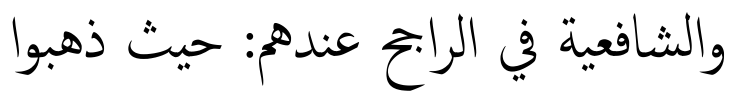

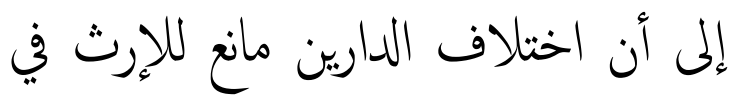

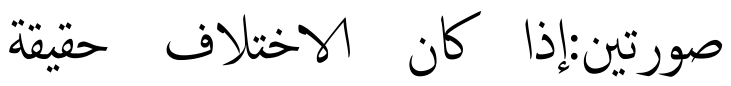
وحكا كأن يموت الذي في بلاد الإسلام وله قريب في دار الحرب فلا يرثه. وإذا كان الاختلاف حكما فقط: كأن يموت فئ وان مستأمن في دار الإسلام، فلا يرثه قريبه

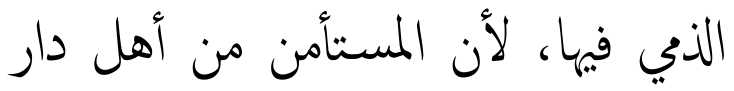

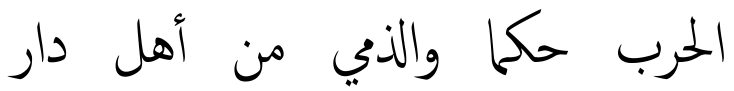
الإسلام حقيقة وحكا. فاختلاف الدارين دن انقطاع الولاية بينها، فلو ماتئلوات الوات 
المستأمن في دارنا يرثه قريبه في دار

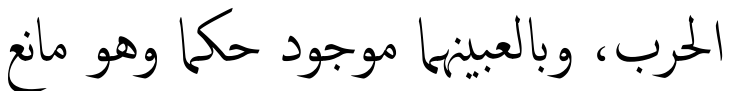
الميراث، أما اختلاف الدار حقيقة لانيان حكما، فليس مانعا للإرث لعكس، لأنها

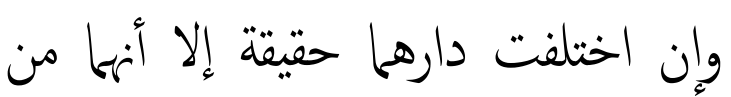
دار واحدة حكما، فلا يكون.

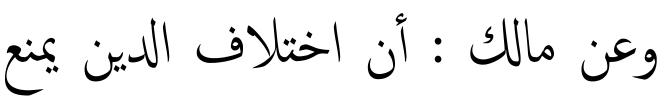
ثبوت الولاء للكافر على المسلم لقوله

$$
\text { تعلى : }
$$

\}والذين كفرؤا بعضهم أولياء بعض\{(الأنفال : 73)ولأن الولاء

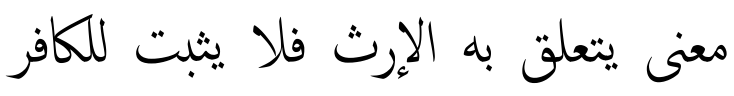

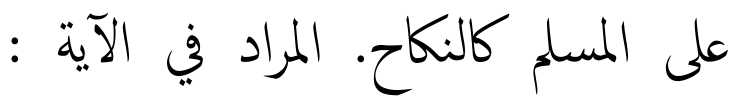

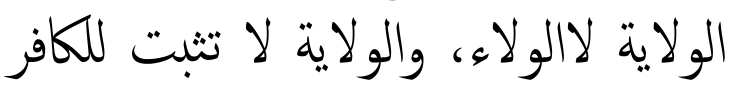

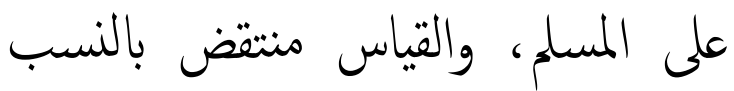

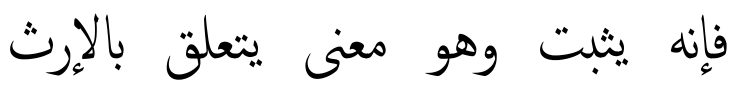

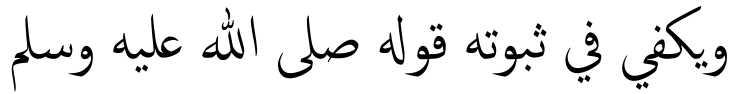
:

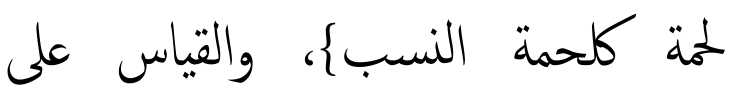

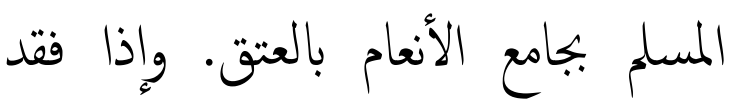
المعتق، فالأحق به أي بالتعصيب أي الماني

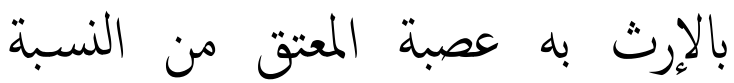

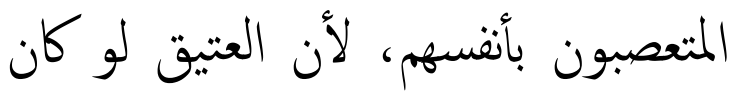

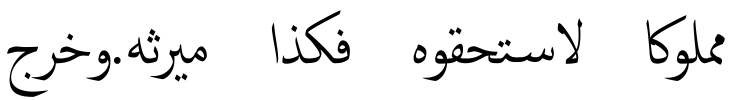
بالعصبة غيرهم كألام، وبالنسب العصبة فئن
بالولاء، وبالمتعصبين بأنفسهم العصبة

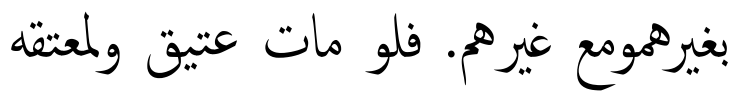

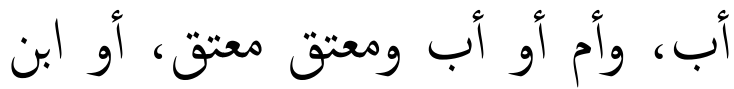

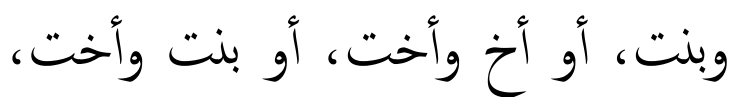

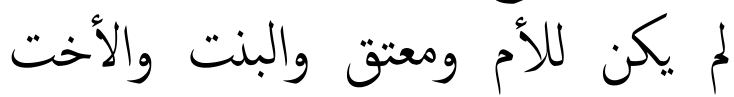

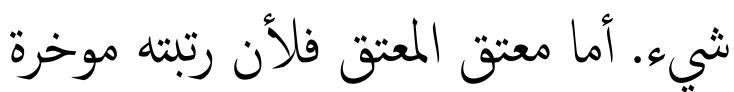

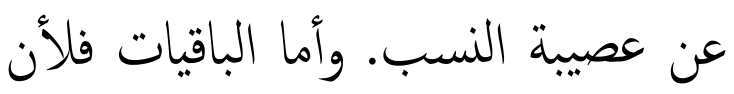
النساء لاترثن بالولاء إلا من أعتقن أو الو النيات أعتقه من أعتقن أو جر (15) الولاء إلبهن

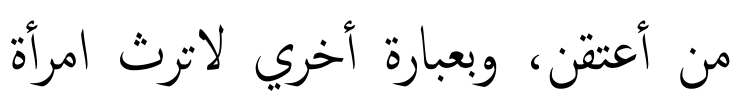
بولاء إلا معتقها أو منتميا إليه بنسب أو لأون ولاء.

وصورة انجرار الولاء كما سيأتي :

أن يتزوج عبدها معتقة شخص فتأتي منه بولد فولاؤلموالي أمه ثخ تعتق المرأة عبدها

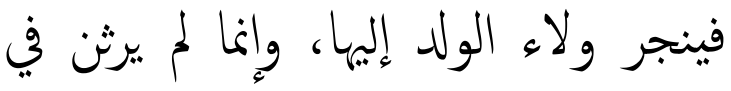

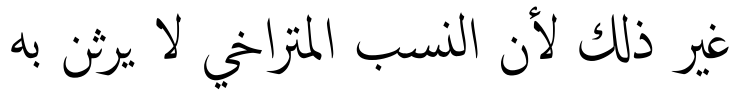
كبنات الأخ وبنات العم.

فالولاء الأضعف من النّات النسب

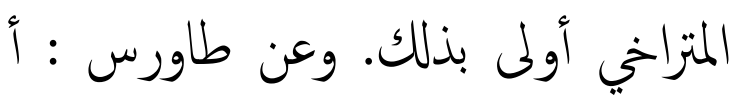

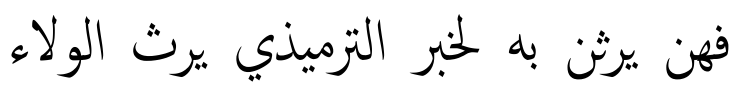

(15) الجراي الجذب. وجر الولاء ثابت

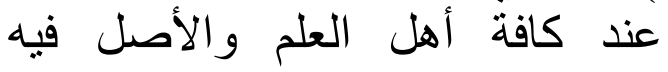

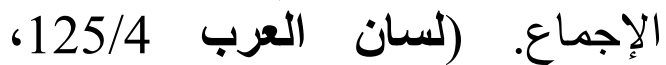
العزيز شرح الوجيز 387/13) 
من يرث المال، ولخبر النسائي : أن مولا

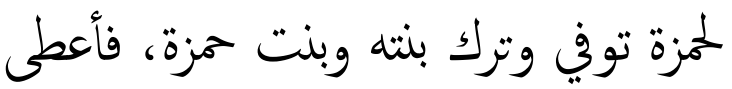

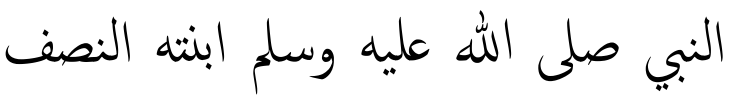
وابنة مززة نصف ولأن المرأة والرجل النقل سواء في الإرث بالولاء مباشرة؛ فكذا هنا قلنا : الخبر الأول ضعفه

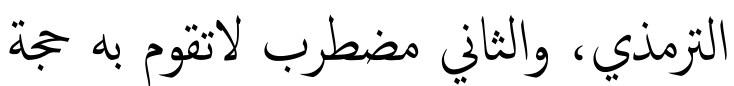
كما قاله السبكي، قال والني رواه النسائي

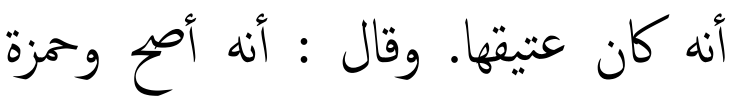
المذكور ليس هو عز النبي صلى الله عليه وسلم بل حمزة آخر. قاله الروياني : وأما لماليه

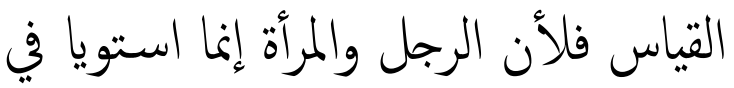
الإرث مباثرة لاستوائها من بجة الأنعام وليس كذلك هنا فإن الإرث فيه إنما هو

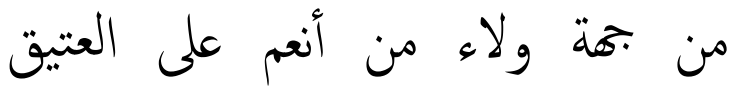

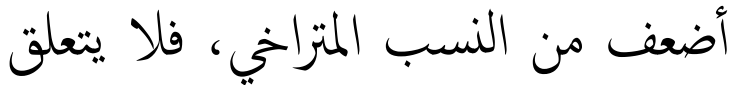
به الإرث ذكره القاضي أبو الطيب.

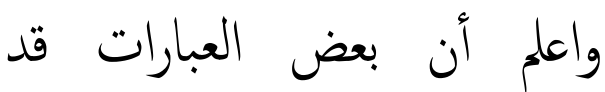
تقتضي أنه لايثبت الولاء اللعصبة الأبعد

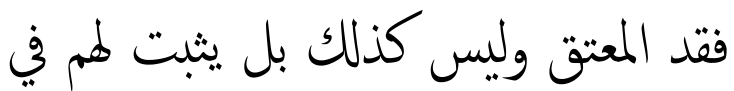
حياته على المذهب المنصوص : في الأم

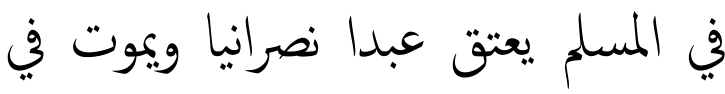
حياة المعتق وله أولاد ذكور نصارى على ألى الدين العتيق، أنه ميرثونه وإن كان أبوهم

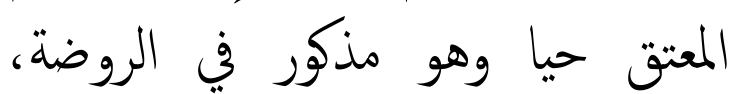

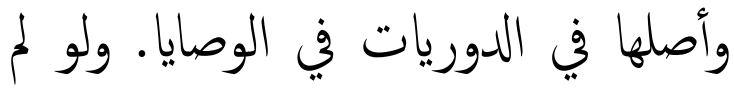

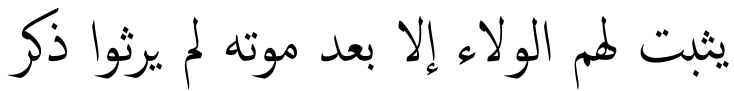

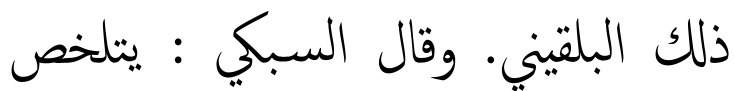
للأصحاب فيه وبجان، أصحها : أنه لم لم

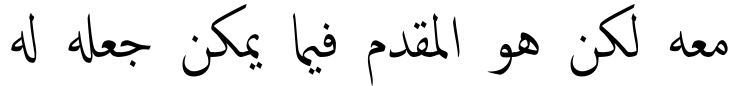

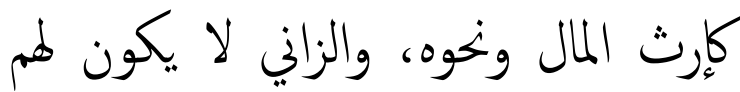

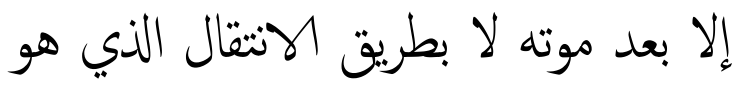
الإرث كما أوهمته عبارة التنبيه التهي. وقد الاند

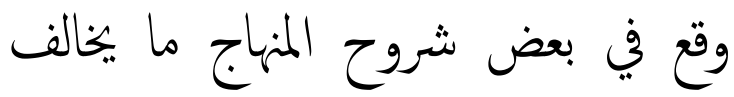
ذلك فاجتنبه.

إذا قيل : وإن كان بحيث يكون عاصبا له لومات المعتق وهو على دينه إلى آخره أي إنما يكون العاصب أحق إنق بتقدير أن يكن عاصبا للمعتق أي وارثا له الها

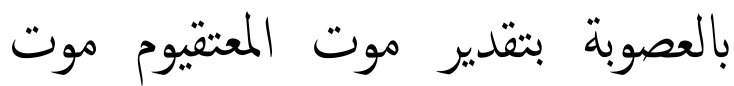
العتيق على دين العتيق. فلو مات العتيق مسلما وكان المعتق كافرا وله ابنان مسلم كلم كلئ وكفر، كان ميراث العتيق للابن المسلم لصدق التقدير عليه دون الكافر. ولو لوكات المان مات كافرا وكان المعتق مسلما ورثه ابنه

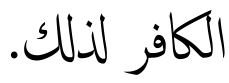

ومن فروع ذلك ما لو مات المعتق عن ابنين ثم مات أحدها عن ابن فولاء

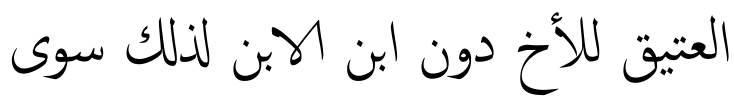
شريح بنهها لانتقال نصيب الابن الميت الميت 
إلى ابنه لنا أن الولاء لا يورث، وإنما

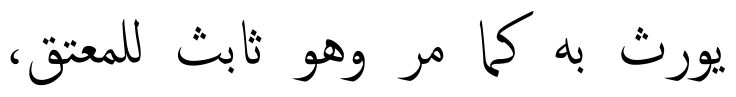
وورثته مأخذون على الأقرب فالأقرب. ولو مات المعتق وخلف ابنا، وابن ابن الحنا

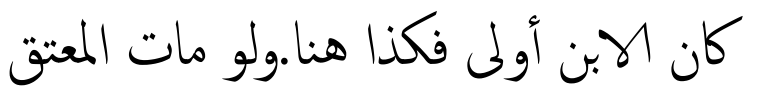

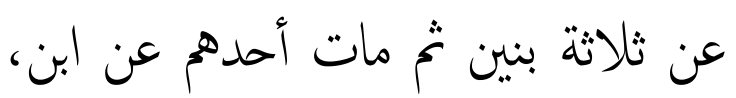

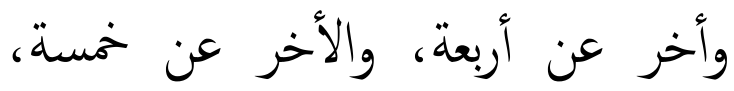

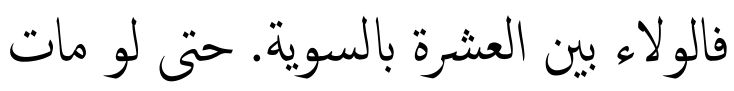
العتيق ورثوه إعشارا لأنه لو مات المعتق لونق يومئذ ورثوه كذلك لأنهم يرثون بقرابتهم من المعتق وهم فيها سواء.

وهذا يخلاف ما لو ظهر للمعتق فواه

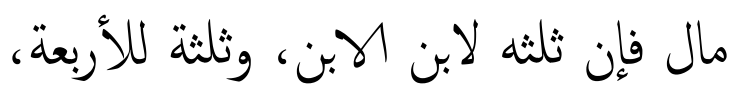

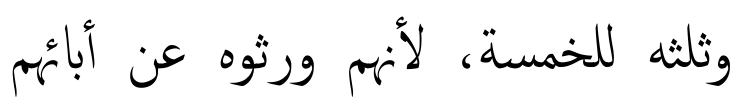
والولاء لم يرثوه. فإذا مات العتيق نظرنا لإنه

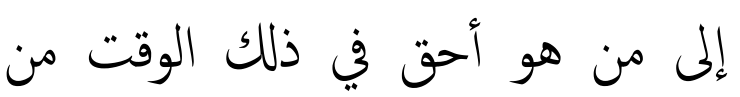

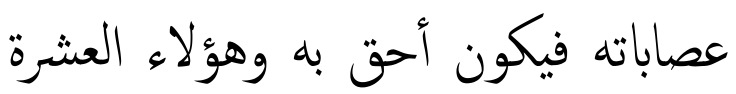
سواء في ذلك فسوينا بينه.

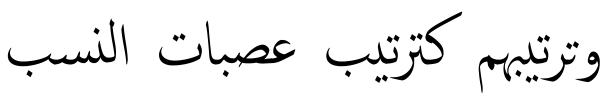

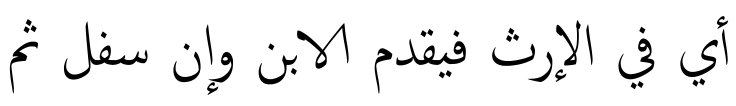

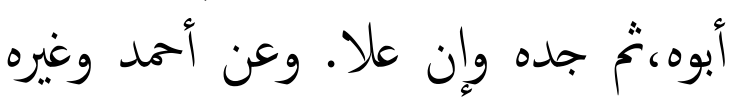

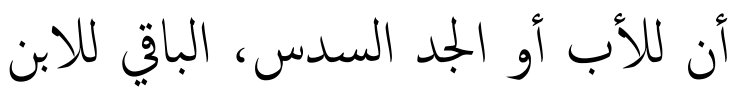

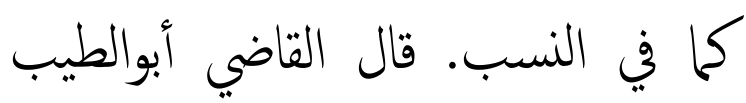
وهو غلط لأن الابن يسقط بتعصيب الأب بالاتفاق، وإذا سقط تعصيبه لم يبق لإن ليقط
إلا مجرد الرحم وهو لا يتعلق به الإرث

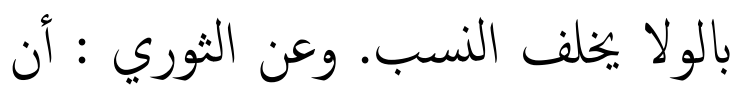
المال بين الأب والابن نصفين لأن كلا لأل النا منها لو انفرد لأخذه كله فيجعل بينها عند الماند

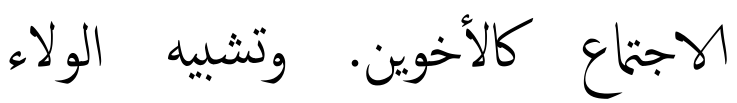

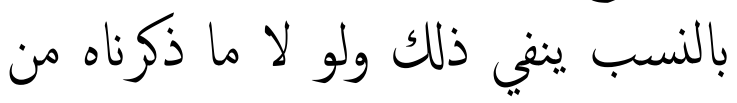
أنه لم يفرد له مع الابن في الولاء لكان حكمه كما في النسب. ثم استثنى المصنف من الترتيب السابق ست صور من بجته جريان الخلاف فقط كما استراء الأولي أن يجتمع الأخ والجد. وفيها قولانا: أحدها أنها الخان

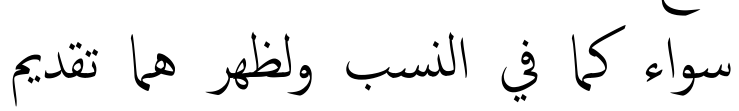
الأخ لأدلائه بالبنوة والجد بالأبوة، والبنوة أقوي وكان قياس ذلك تقديمه في النسب لإنب

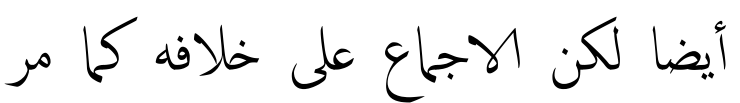
فسرنا إليه في الولاء إذا لا اجاع، خلاع، وعلى ألى الأول طريقان : أحدها : فيه وبجان، أحدها : أن للجد الحيز من المقاسمة والثلث كما في آلثان النسب. وأصحها المقاسمة أبدا لأنه في

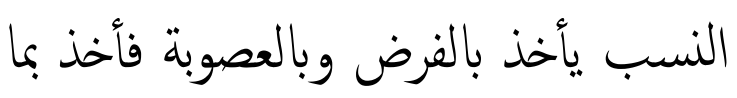

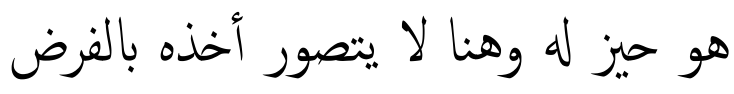
وها في العصوبة سواء فسوي بنهنها. 
والطريق الثاني : وهو المذهب

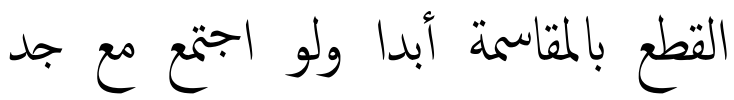
المعتق أولاد الأبوين وأولاد الأب، فهل فهل

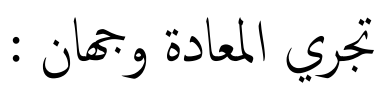

أحدها : نعم كما في النسب وأصحها لا لا لأن إدخال أولاد الأب في الحسب في في باب النسب قد يحصل لمم به شيء كما

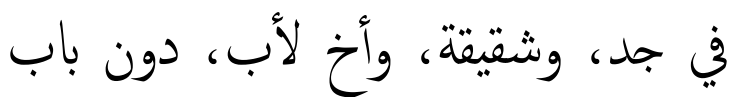

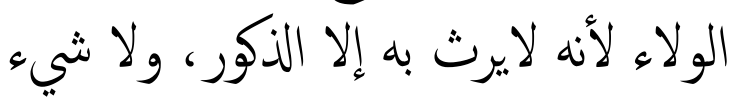

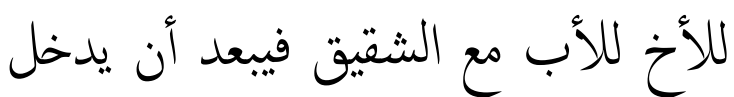

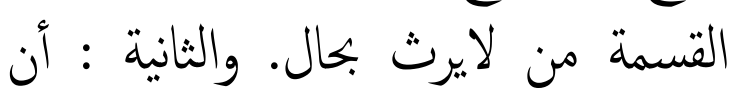
يجيتمع ابن الأخ والجد وفيها قولان أيضا.

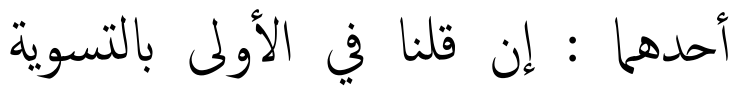
فالجد هنا مقدم لقربه. وقيل : هـا سواء. وإن قلنا : فيها بتقديم الأخ فكذا لقدا ابنه تقديما للجهة القوية فنترج من ذلك ثلاثلة

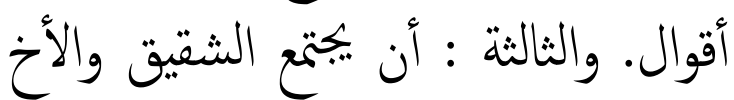
للأب، وفيها طريقان أصحها القطع بتقديم الثئ والئ

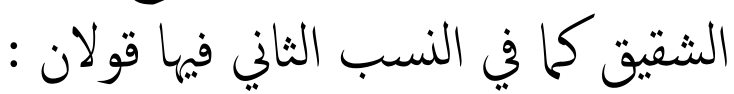

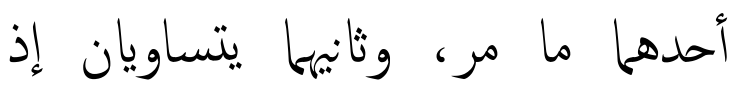
لادخل لقرابة الأم هنا. والرابعة والخامسة التهان

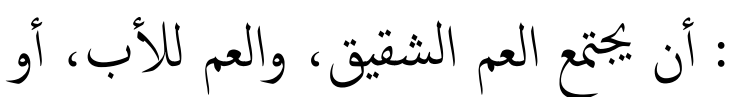

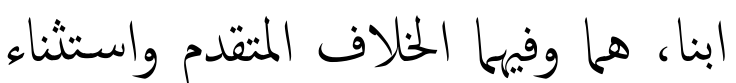
هذه الثلاث من ججة جريان الخنلاف فيها خاصة. وقياس ذلك أن يذك ابني الأخ
الشقيق والأخ للأب.والسادسة : أن

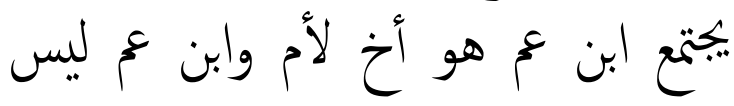

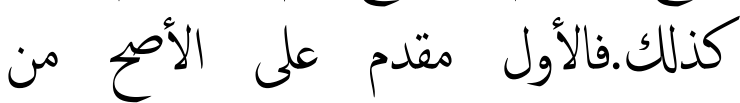

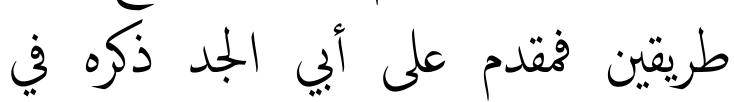
الروضة وينبني كما قال البلقيني: تقديم البيم ابن العم المذور على أبي الجد.

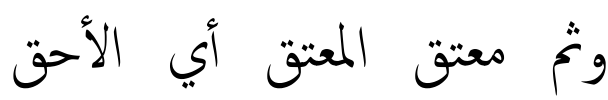
بالميراث بعد عصبات المعتق ثخ عصبته

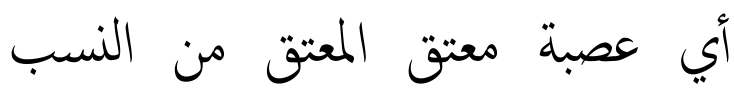

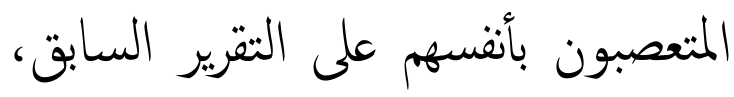

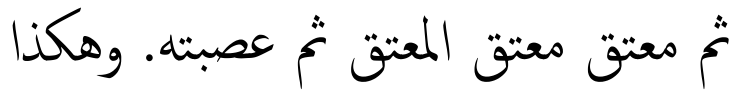

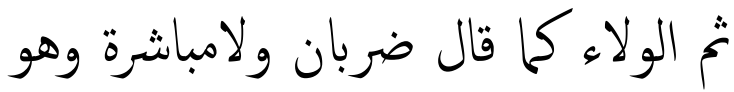

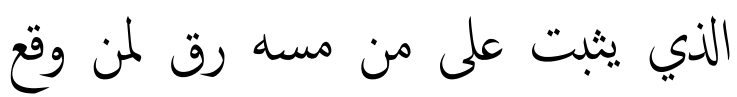
عنه العتق، وولاء سراية وهو الذي مني من وفي

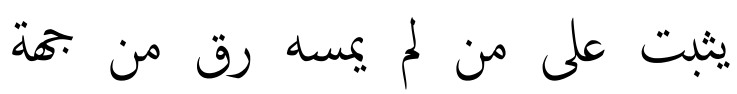

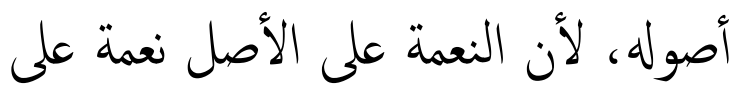

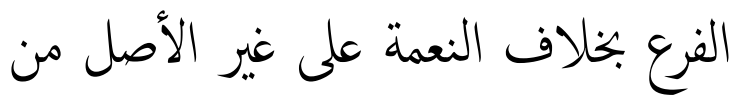
الفرع وغيره لا تتعدى إلى غيره، وله كما قال شرطان لكنها بالنسبة إلى أولاد

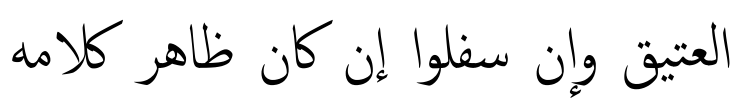
بل صريحه عودها إلى عتلى إئه وعتقا عتقائه أيضا : أحدها : أن يكون الرق قد مس أحد

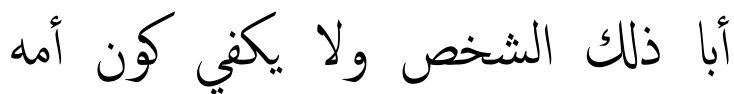

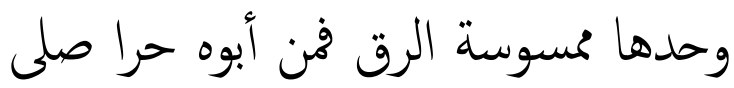




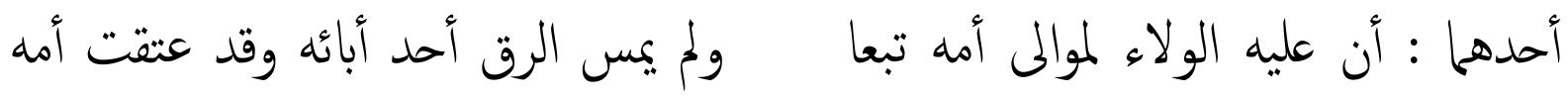

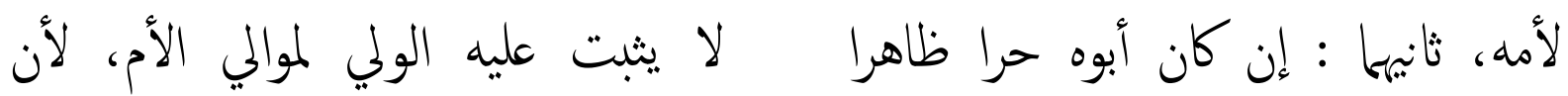

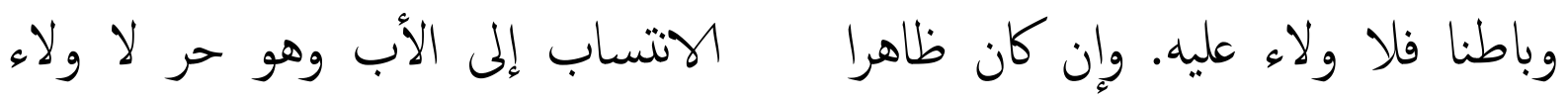

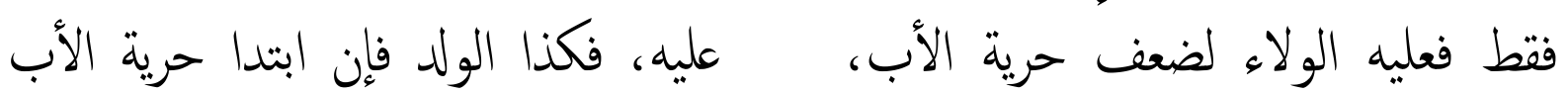

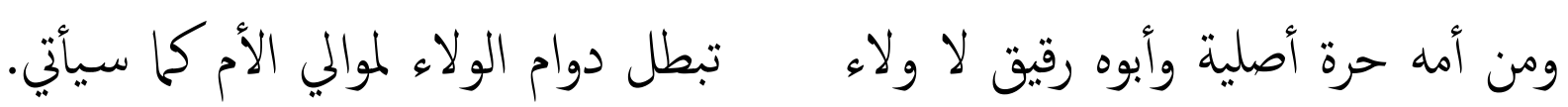

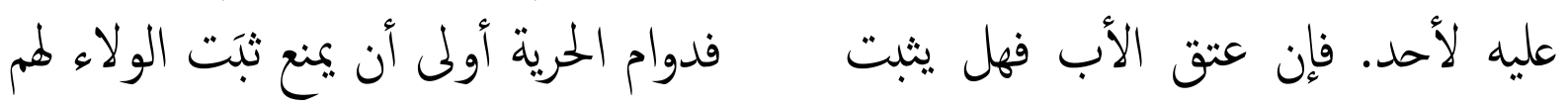

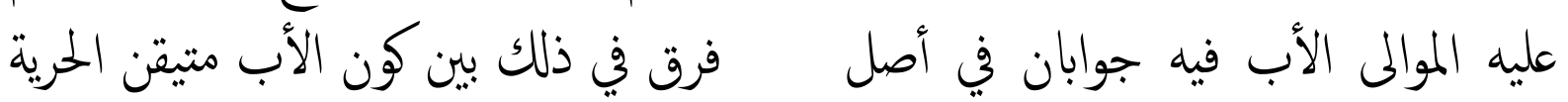

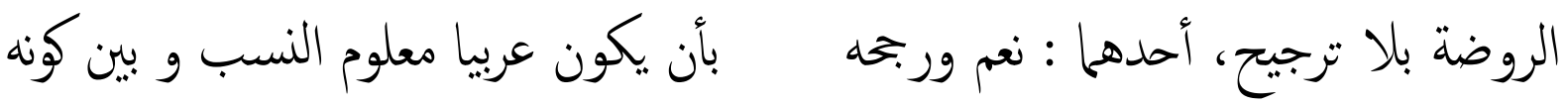

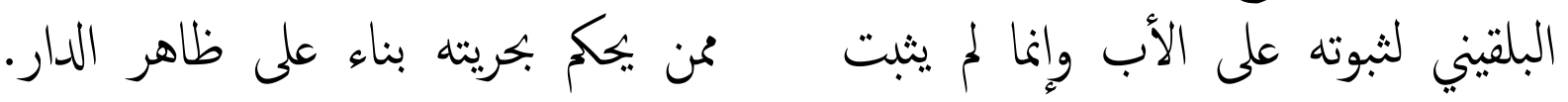

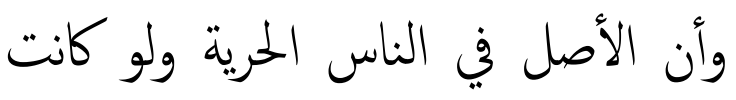

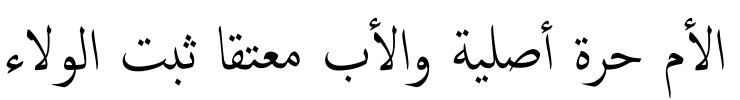
عليه لموالي الأب لأنه ينسب إليه.

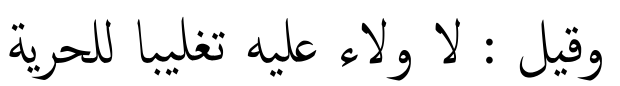
ككسه الثاني أن لا يكون ذلك الشخص قد مسه رق، فمن مس الرق أحد أبائه

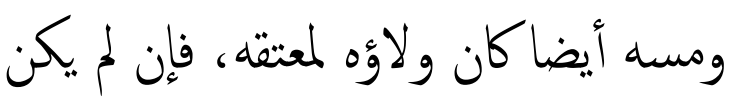
فالعصبات معتقه على ما مر فان لم يكونوا فلبيت المال. ولا ولاء عليه لمعتق أصوله

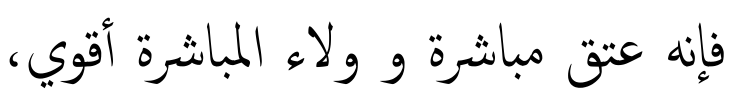
إلا إذا كان فيهم أي في الأولاد، وأولاد

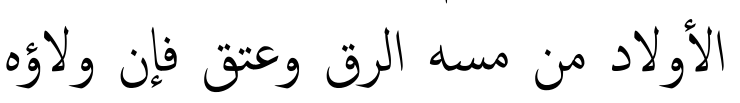

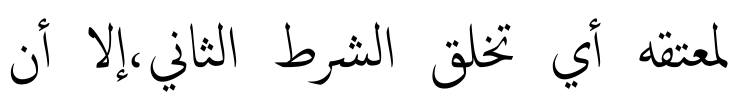

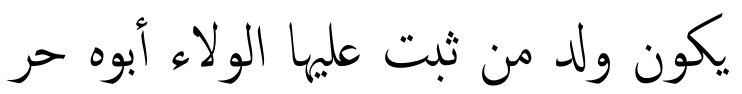

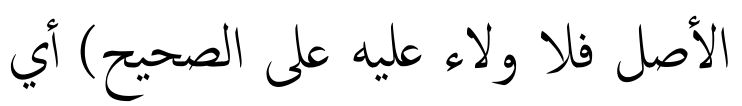

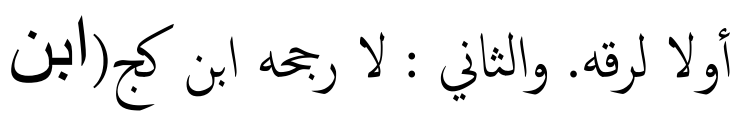
قاضي شهبة 196/1) لأنه لم يثبت ابتداء فكذا بعده كما لو كان أبواه حرين (ضـــابط) لا يتصور أن يكون

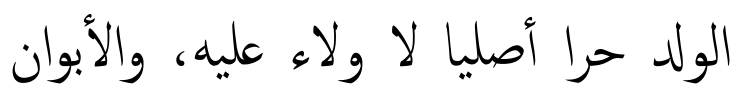
رقيقين إلا في السبي بأن يسترق الأبوان

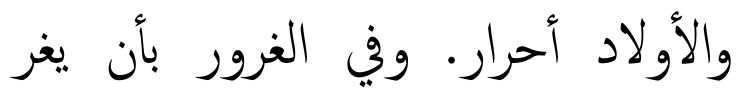

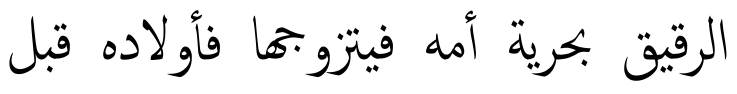

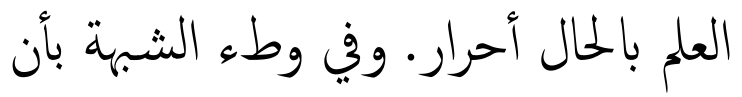
يطء الرقيق أمه الغير على ظن أنها زوجته الحرة فأولاده منها أحرار. وفي الفي

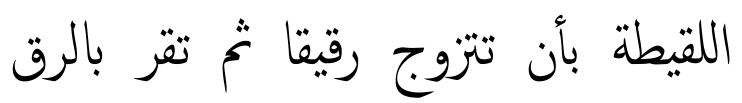
فأولادها قبل الإقرار أحرار.

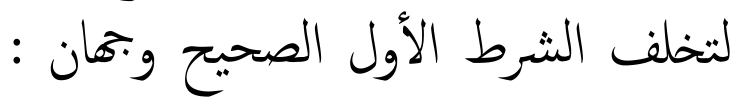


قوله : (فإذا اجتمع معتقا أصله إلى إلى

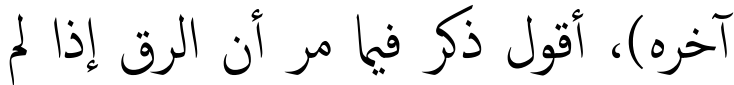

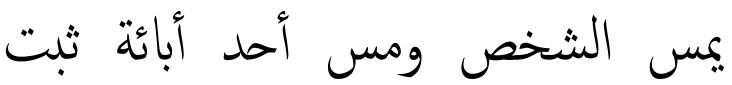
الولاء عليه لمعتق أصله، ثخ ذكر هنا أنه أنه

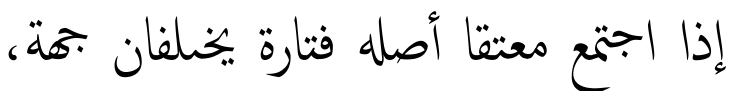
وتارة يتحدان فيها وعلى الثاني إما أن إن إنان يختلف عتيقا هها ذكورة وأنوثة أولا. فإن ان اختلف بهة قدم بجة معتق الأب على دورة ألى جهة معتق الأم، لأن معتق الأب أولى معنى الاب على

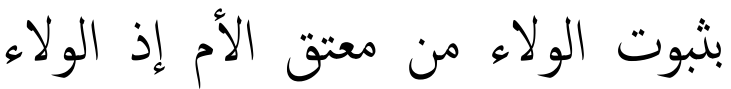
لمحة كلحمة النسب،والنسب إلى المي الأباء

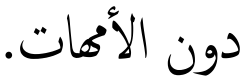

وإن اتخذا بجة واختلف عتيقا هـا

ذورة وأنوثة قدم معتق الذذك على معتق الأثنى، وإن تساويا قر بالقوة جهة الأبوة.

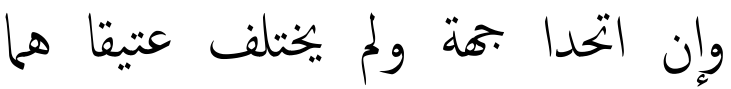

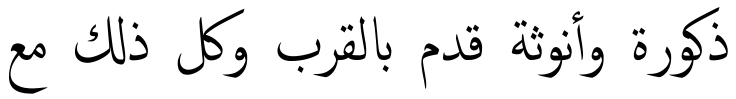
أمثلة ظاهر من كلامه. ثم ذكر أن ولاء سراية هو محل مله الإنجرار بخلاف ولاء المباثرة أقوى منها

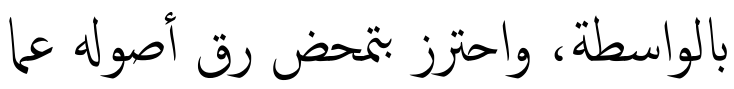
إذا كان بعض أصوله حرا، فإنه لايثبت

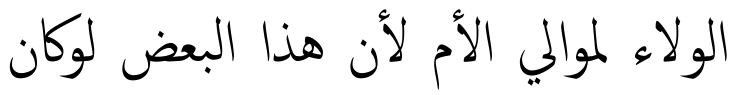

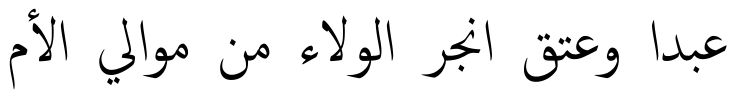

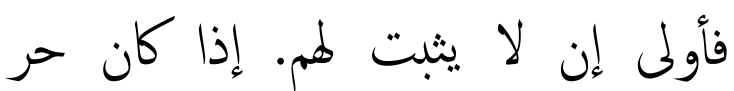

الأصل وإنما انجر الولاء من موالي الأم

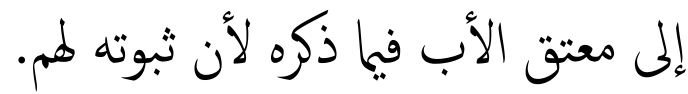

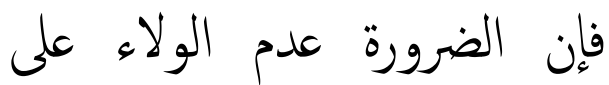

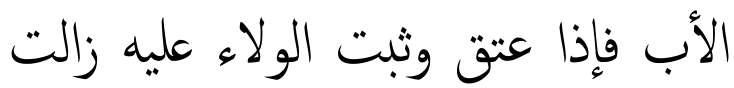

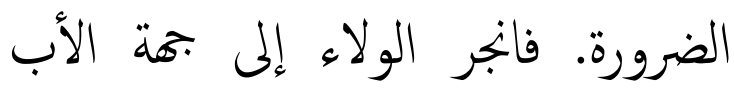

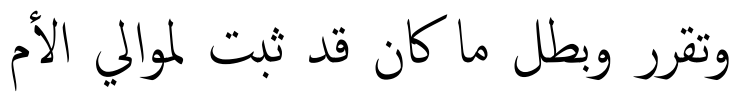

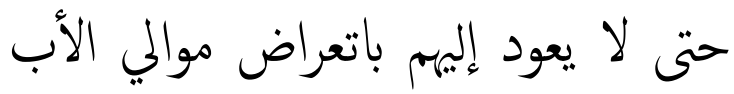
نعم لو لحقوا بدار الحرب وكانوا كفارا فسبوا واستسرقوا. ففي عوده إلى موالي الأم وبحان

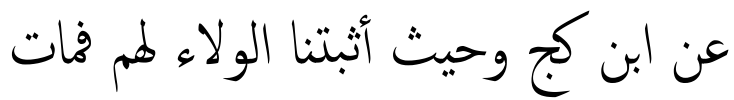

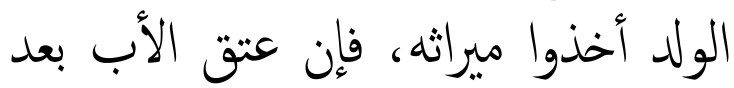
ذلك لم يكن لمعتقه استرداده إذلم يكن له اله ولاء عند موته. وليس معنى الانجرار إنا

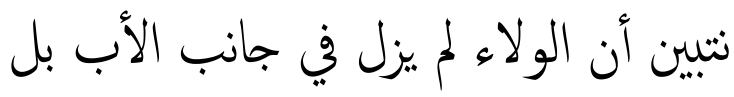
ينقطع من وقت عتقه عن موالي الأم المان

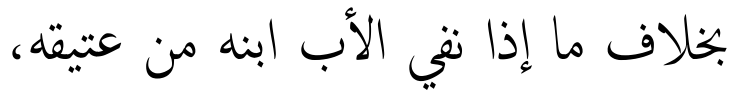

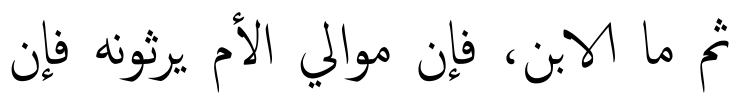

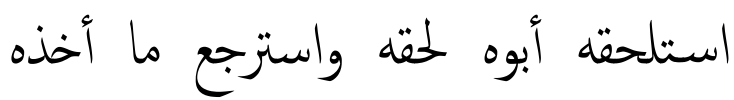

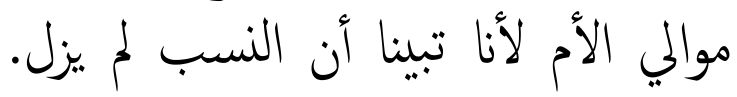

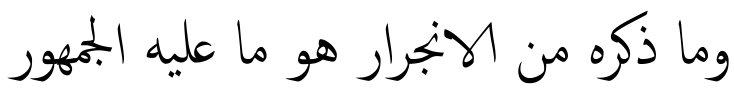
لما مر أن جهة الأبوة أقوى. وعن مجاهد وغيره لانجرار الخبر :

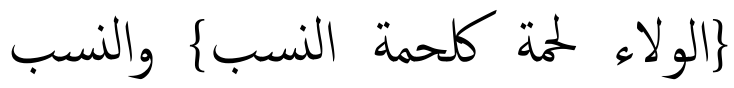

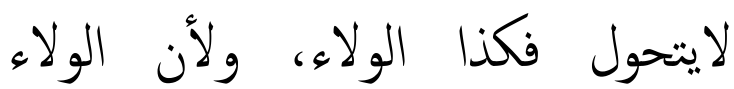


بالمباشرة لاتحول فكذا هذا، وأجيب بأن الخبر لنا لا علينا لأن النسب إلى المأل الأباء

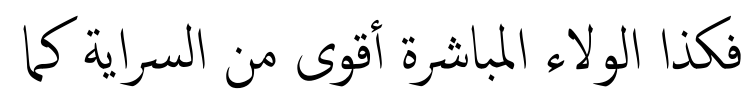
مر، وهذا كولد الملاعنة ينسب إليها

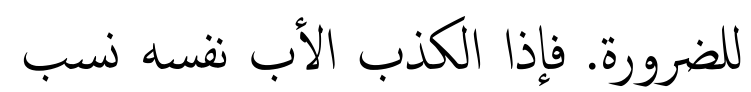
إليه لارتفاع الضرورة. فلوكان المعتق هو جد الولد أي الوني لو عتق الجد في حياة الأب، فالأصح انجرار الولاء من موالي الأم إلى موالي الجد لقيام الجد مقام الأب، والثان الثاني

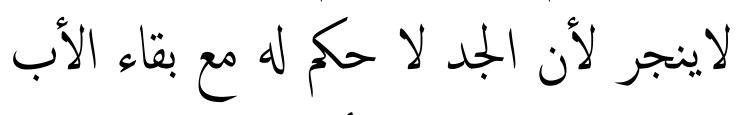

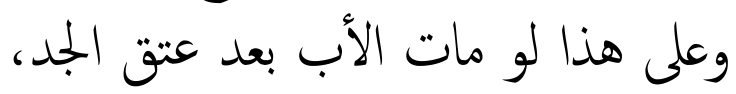

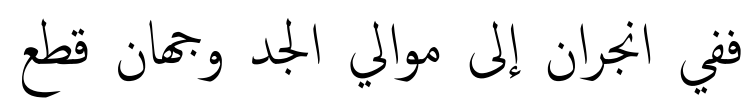
البغوي بالانجرار. وقال في الروضة : إنه إنه

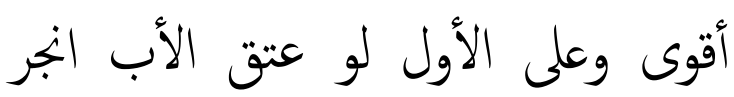
الولاء من موالي الجد إلى مواليه واستقر عتى الاب الهر حتى لو لم بيق من مواليه أحد لم لم يعد المداء الولاء إلى موالي الجد لانقطاع ولاءيتهم بل يكون الميراث لبيت المال، ومراده

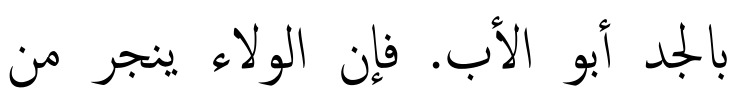

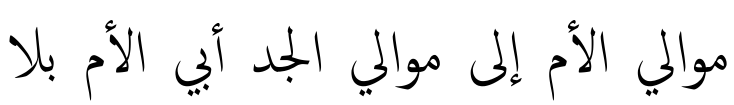
خلاف.

وأثشاربقوله : فلو اشتري الولد المذكور إلى أنه لو ملك هذا الولد أباه

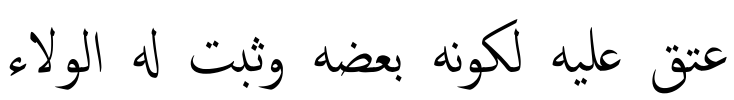

عليه لما مر وجر ولاء إخوته إليه بلا خلاف. والمراد إخوته من أبيه سواء كانوا

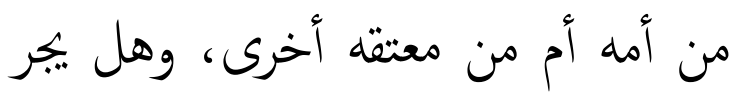

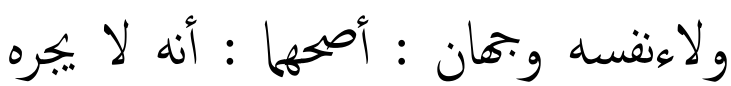
لأنه لا يككن أن يكون له علي نقسه ولاء.

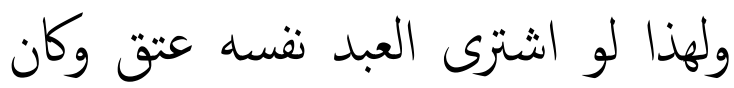

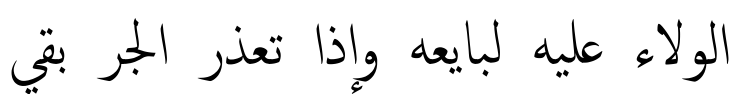

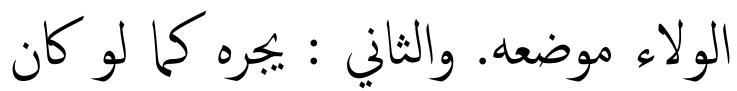
المعتق غير الولد ثم يسقط ويصير كحر لا لا ولاء عليه.

قال ابن الصباغ (ابن قاضي شهبة 269/1)والروياني : وفيه نظر لأنه يؤدي إلى ثبوت الولاععلى أبويه

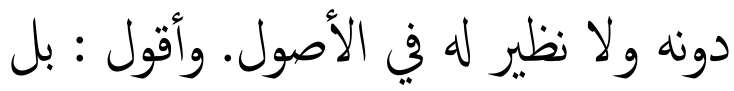

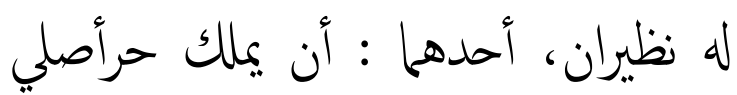
أبويه فيعتقان عليه. ثانيها : على ما في في أني المطلب أن يطرأ رق أبويه وها حران

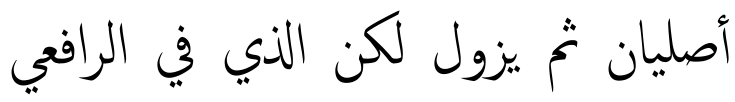
ثبوت الولاء عليه. قال الزركثي: وفيه نظر.

ولو أعتق أمته المزوجة: تضمن كلامه مسألتين : أحدها : أعتق أمتنه

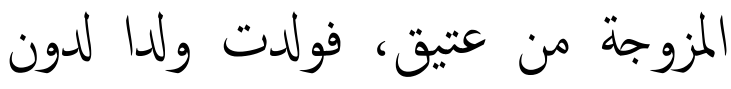
ستة أشهر من الإعتاق فولاؤه لمعتق أمه وله 
لأنا تيقان وجوده وقت الإعتاق فمعتقه باشرا عتاقه باعتاقها. وولاء المباشرة مقدم الاعناف فكان لموالي الأم أو ولدته لستة أشهر

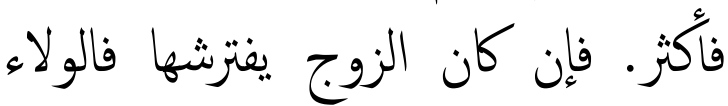
لمعتق الأب لأن نغلم وجوده وقت وقت

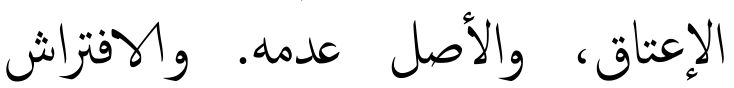

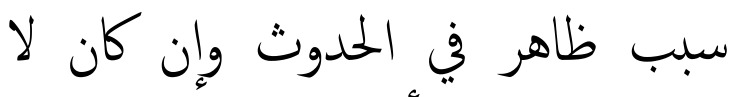

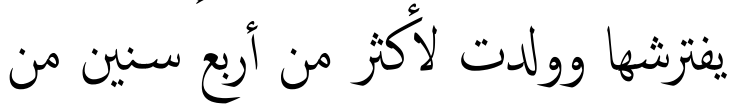
الإعتاق فكذلك أو لأقل، فالولاء لإن لموالي

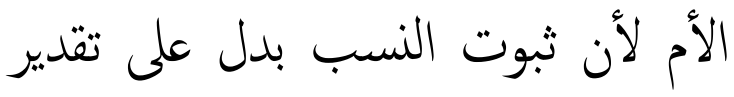

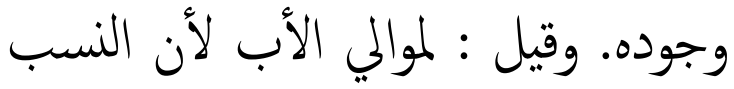
يكفي فيه الإمكان بخلاف الولاء. الثانية : أعتق أمته الزوجة مناف لولاه

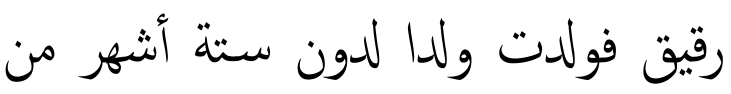

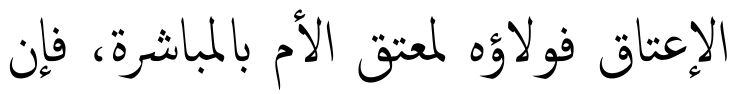

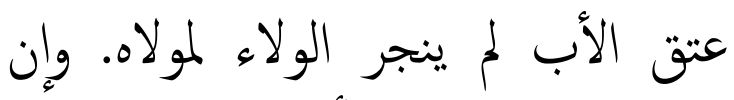

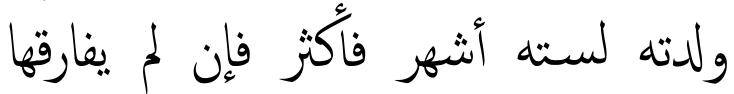

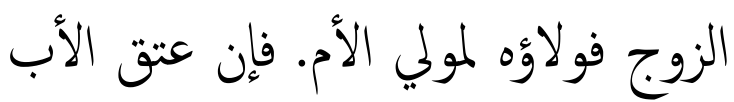
انجر إلى مولاه وإن فارقها فإن وليست

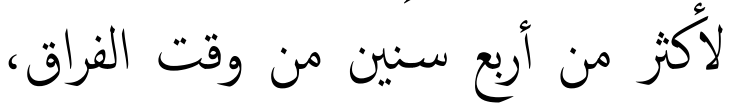
فالولد منفي عن الزوج وولاؤه لمعتق الأح

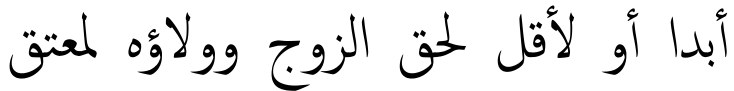

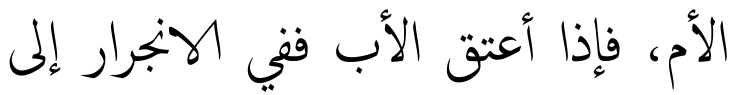
مولاه قولان : لم يربح المصنف منها شيئا

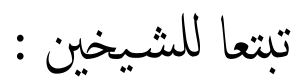

أحدها : وبه جزم ابن الصباغ

والروياني : أنه لا ينجر لأنه ولاء مباثرة إنها

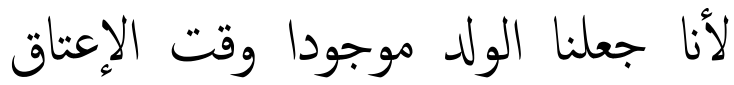
لثبوت نسبه من الزوج. والثاني : ينجر الأنا

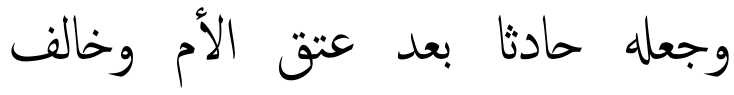
النسب فإنه يثبت بمجرد الإمكان وكان

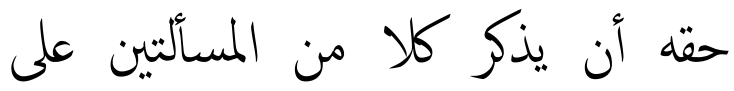

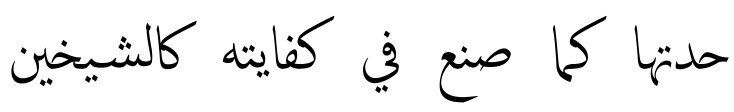
ليتبين المراد مع أن قوله وإلا فلموالي الأب غير محرر لشموله الثانية مع أن أن فئل

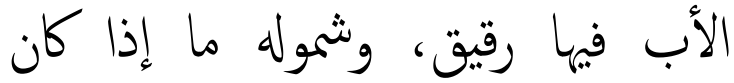

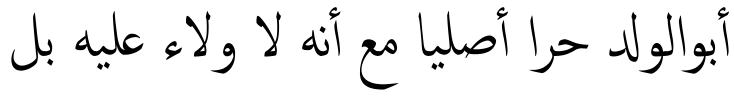

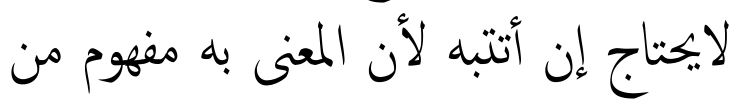

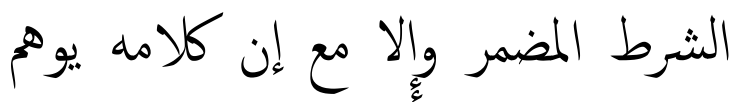

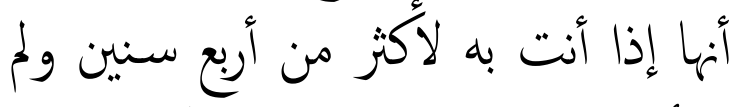
يطأها فالولاء لمولي الأم وليس كذلك آنك بل بل هو لمولي الأب كما مر.

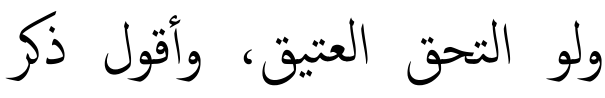
مسألتين : إحداهيا : إذا أعتق المسلم ذميا والئ

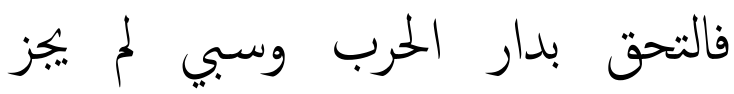
استرقاقه لأن المسلم لايسترق فكذا عتيقه

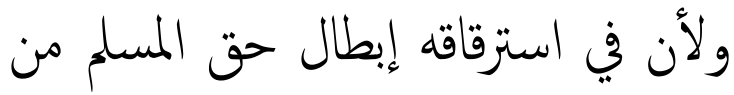
الولاء وفيه قول : يخرج من أن إسلام إنطام

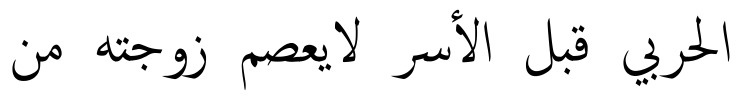
الاسترقاق على الأصح، إن الولاء لا يرتنع الإنئ من 
وإن تراضيا عليه خلاف النكاح. الثانية :

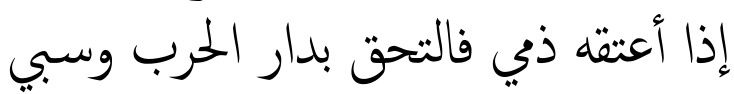

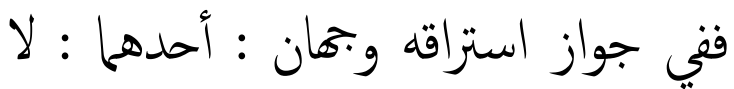

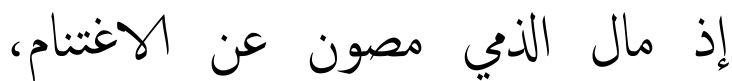

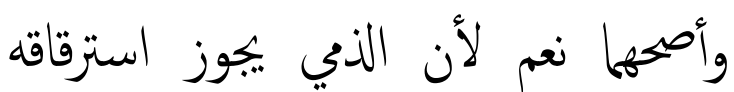
فكذا عتيقه بل أولى، والخلاف في هذه

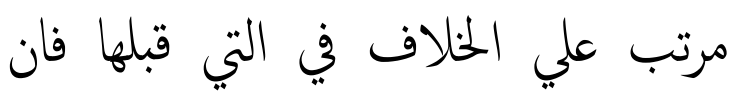

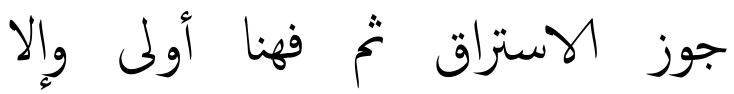
فونجان، أصحها الجواز.

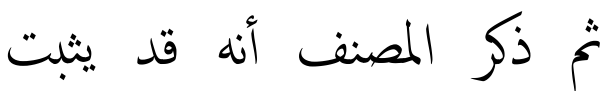

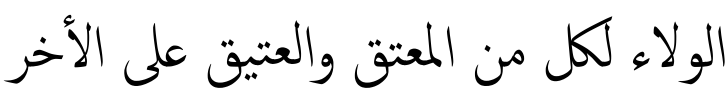

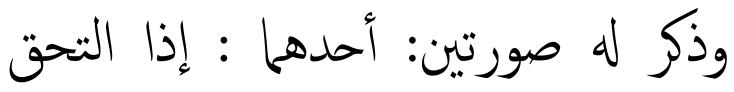

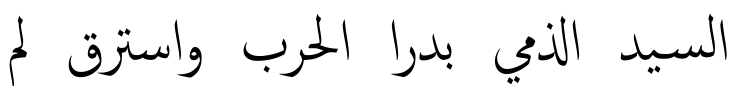

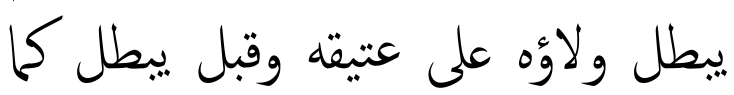
يبطل ملكه على عبده، فعلى الأولوملكه عتيقه فاعتقه كان لكل منها الولاء على كلى الأخر مباشرة. الثانية : إذا أعتق من عليه الولاء لموالي أمه عبدا والحال أن أبها المعتق رقيق فملك العتيق أبا سيده

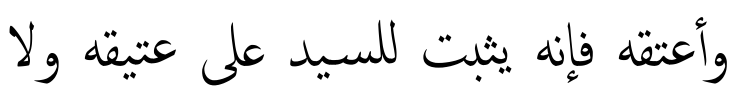
المباشرة ولعتيقه عليه ولا السراية.

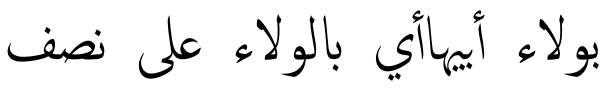
أبيها مباثرة لأهها معتقة نصفه بالثري. وقوله: (بولاء أخها) أي بالولاء على نهلى نصف أخها سراية من أبيها فورثت اثتاه
البنت بثلاث بجات : بجة فرض وبجتي ولاء.

وقوله : (والربع بأنها معتقة نصف أبيها) أي فيسترسل نصف الولاء على إنى

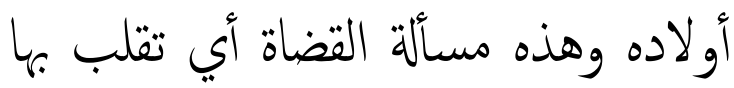

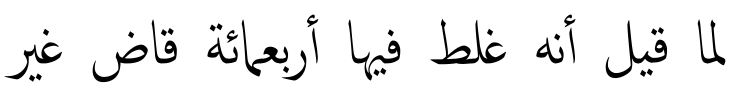

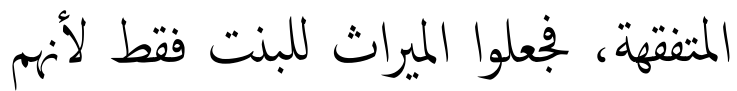
رأوها أقرب وهي عصبة له بولاهيا وغفلوا

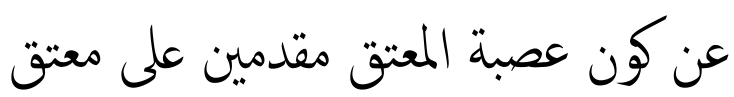
المعتق.

وصورها في الوسيط بابن وبنت

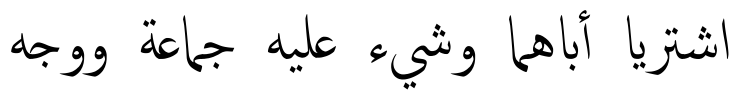
غلط القضاة فيها جعلهم ميراث العتيق بين

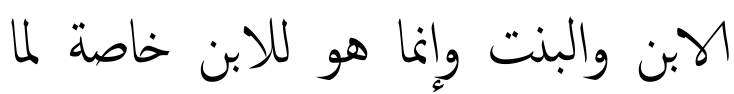

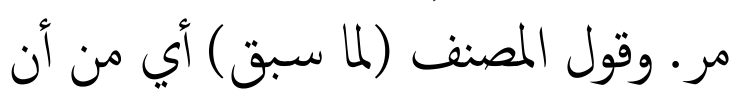
الولاء بالمباشرة أقوى منه بالسراية. واعلم أن الانتساب في الولاء قد المد

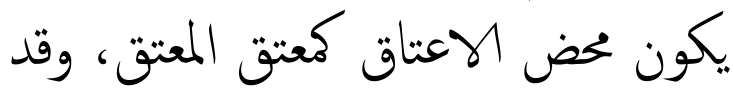

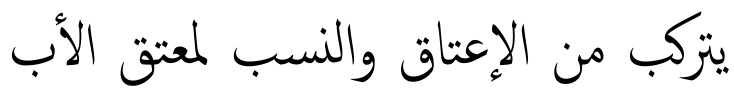

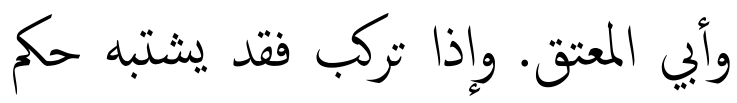
الولاء ويغالط به كان يقال : اجتمع أبو ألمان

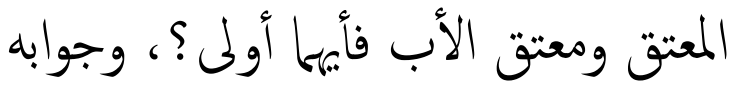

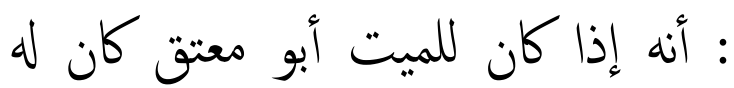

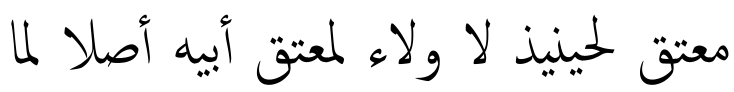

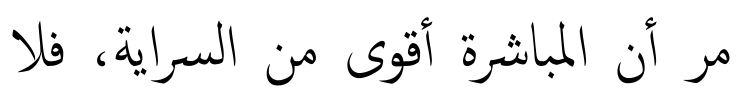




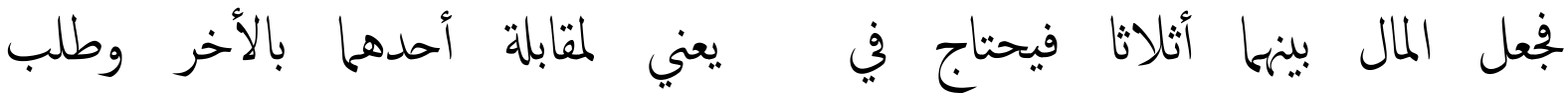

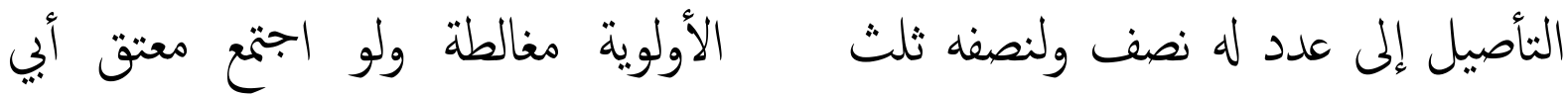

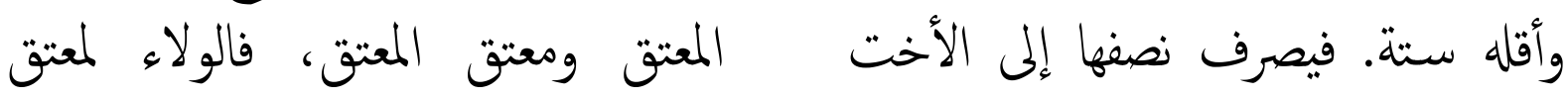

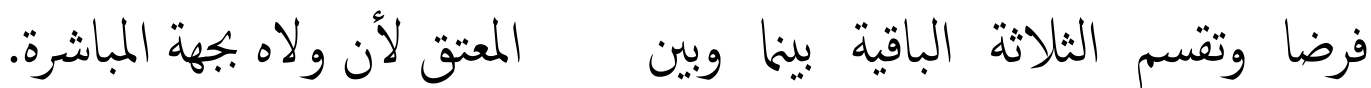
وقوله : (أختان اشترتا أحما إلى

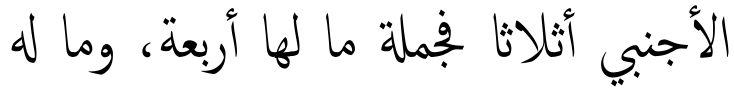
آخره)، أقول : تقريره ظاهر وحاصل ما إنمان

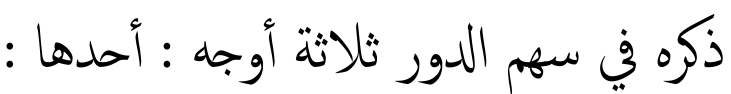

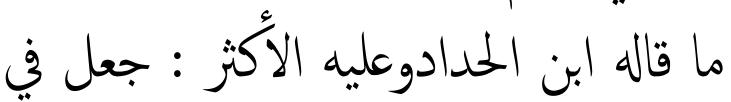
يبت المال لأنه لايكن صرفه لا بالنسب ولا بالولاء. وثانيها : يسقط ويقسم المال على باقي السهام وهو سبعة لكوت

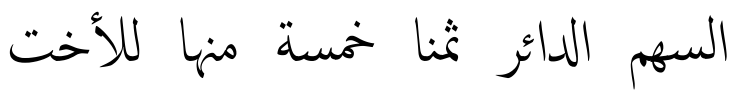
الباقية أربعة بالفرض وواحد بالولاء، الكهاء وسهان للأجنبي. والقسمة على الأول أيضا على للى

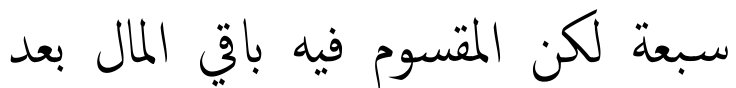
الثمن وفي الثاني جميعه والثالث، وعليه

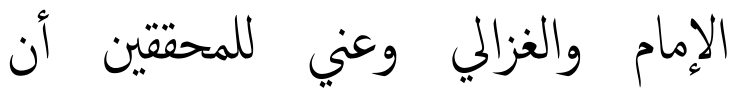
للأخت ثلثي المال ولأأجنبي ثلثه، لأن النان الباقي بعد فرضها نصفه للأجنبي ونصفه للأم، وما للأم يصير للأختين ثم لواحدة لهن منها يرجع نصفه للأجنبي ونصفه للأم.

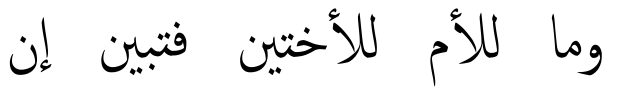
للأختين من النصف مثلي ما للأخت،

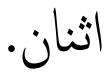

ويرجع بالاختصار إلى ثلاثة ثم ضبط موضع حصول الدور بقوله : (ولا إلان يتحقق الدور إلا بثلاثه شروط إلى آخره)

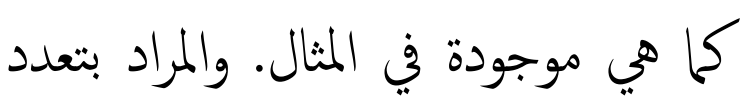

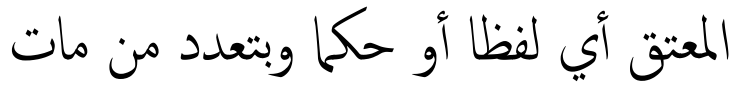

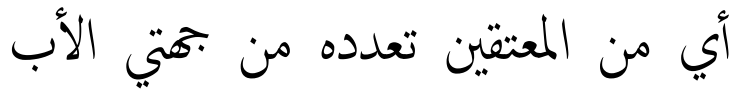
والأم فإن اختل شرط من الثنلثة فلا تلابن دور. فرع : أحدها : لو اشترت أختان

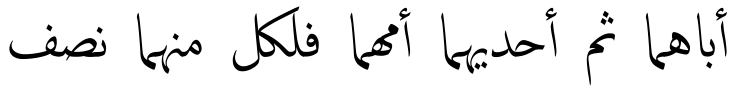
الولاء على الأب والأخرى ولمعتقة الأم الأ

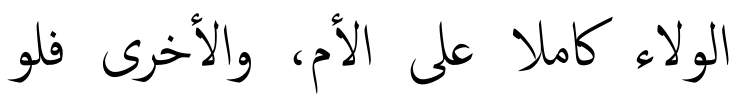

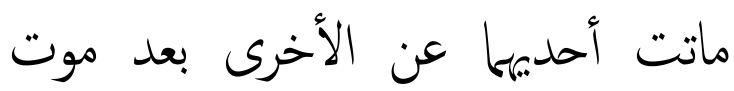

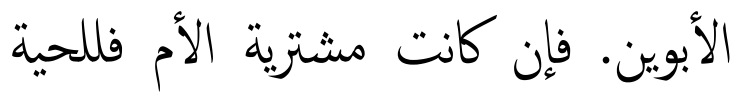

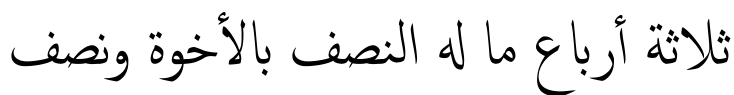
الباقي بالولاء على نصف أبيها. وإن كانت التحة ونصف الأخرى فللحية الكل النصف بالأخوة الناهيا والربع بالولاء على نصف أبيها والربع الأخر بالولاء على أهما. 
ثانيها : ثلاث بنات حرائر لهن

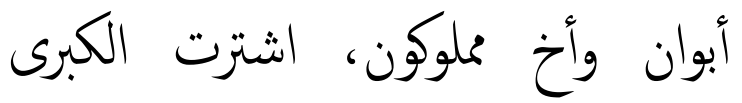

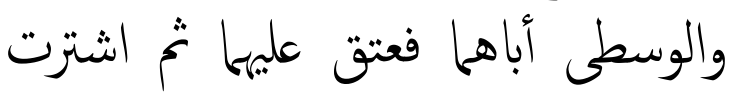
الكبرى والصغرى والأب والأخ فعتق ثلثه الثرت على أبيه بالملك ولم ولم يقوم الباقي عليه لاعساره، فأعثتنه أختاه ثبت عليه الولاء

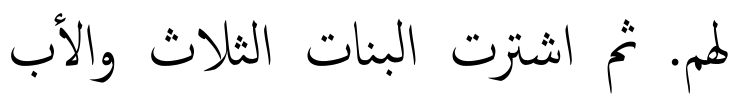

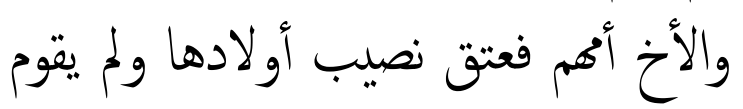
عليهم نصيب أيبيم لاعسار هم فأعتق الأب

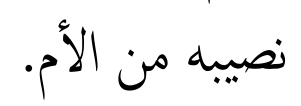
فإذا مات الأب أولا ورثه أولاده

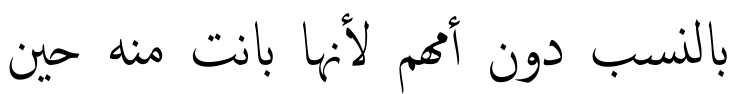
ملك جزها. فإذاذا مات الأخ بعد ورثت الأت مين الأم السدس والأخوات الثلثين بالفرض

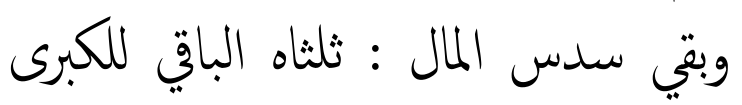
والصغرى لأنها اعتقنا ثلثيه وثلثه الباقي كان مستحقا بولاء الأب، فيكون لمولاتئيه الكبرى والوسطى فتكون المسألة من لمن الآنه ستة وثلاثين، للأم ستة وللبنات أربعة

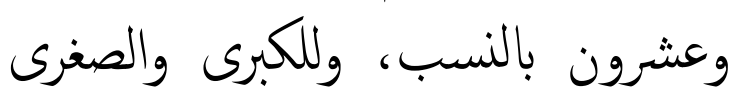
أربعة بالولاء عليه مباشرة، وسهان والكنية

$$
\text { للكبرى والوسطى بالولاء عليه سراية. }
$$

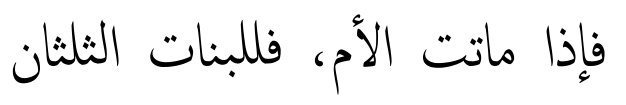

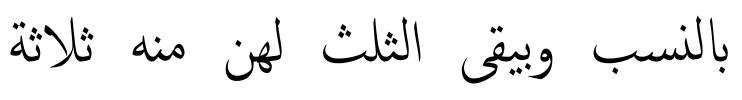
أخاسه بولأهن على أهن وبتي خمساه
كان حق الولاء لأبيهن وأخيهن وخمس

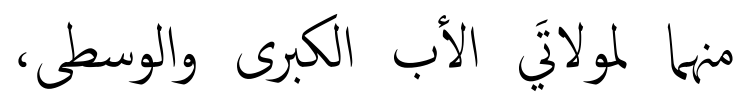
والأخر لموالي الأخ أختاه وأبوه للككبى الأل الكيى والصغرى منه ثلثاه، والثلث الباقي منه

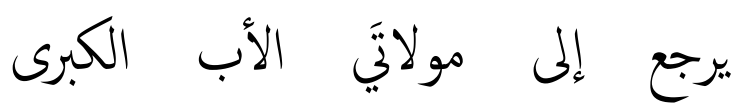
والوسطى، فتصح من تسعين للبنات بالنسب ستون ولهن بأنتاقهن ثمانية عشر. ولمكبرى والوسطى بولأئها على الأب ستة وتبقي ستة مستحقة بولاء الأخ أربعة منها لمعتقتيه الكبرى والصغرى. واثنان يرجعان إلى معتقتي الأب الكبرى المبن والوسطى. ثالثها : شقيقتان لاولاء عليها الشترت

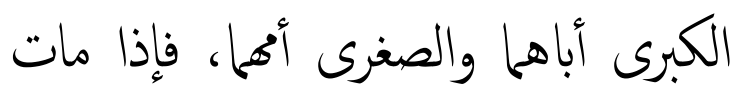

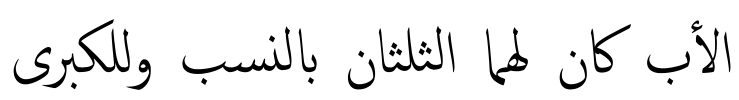
الباقي بولائها عليه أو الأمركان لما الثلثان والبلاقي للصغرى، فإن ماتت الصغرى كان الان النان للكبرى النصف بالنسب والباقي بولائها عليها، يعتق أبيها أو الكبرى كان للصغرى والكي النصف بالنسب، والباقي بولأهيا عليها بعتق أهما.

\section{خاثمة : النتاجُ وأمم الثوصيات}


إن هذا الكتاب الكامل الذي حققته

هو نهنج الوصول إلى تحرير الفصول وهو عبارة عن شرح مطول على الفصول

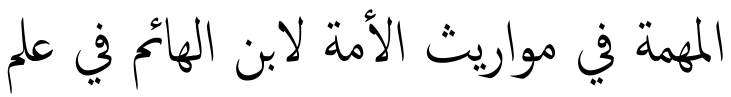
الفرائض، مع أن المؤلف شرح الفصول

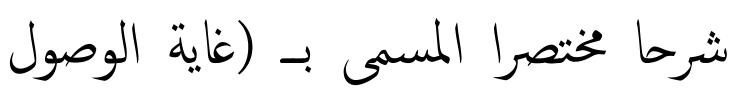

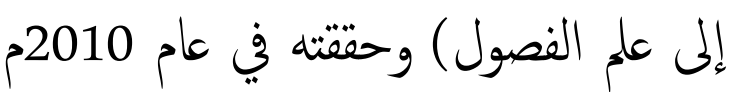
لنيل درجة الماجستير في هذا المعهد. وهذا الثرح المطول قد سبق تأليفه من الشرح الخمتصر حيث إنه ورد في دواعي التأليف في بداية الصفحة من النسخة. وإن هذا الكتاب له أهمية كبيرة لأبواب الفرائض والفقه ولاسيا الحساب. وإن هذا الكتاب يحتوي على ذكر كثير من ولن النه

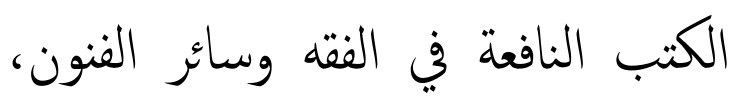
وقد نبه عليها المؤلف-رحمه الله-وأثبنها في كتابه بعد أن استفاد منها. وإن أسلوب المبان المؤلف في هذا الكتاب كان قويا واضحا، وقد سلك فيه النهج العلمي للبحث.

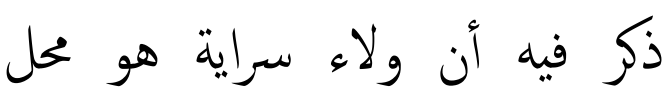
الإنجرار بخلاف ولاء المباثرة أقوى منها بالواسطة، واحتزز بتمضض رق أصوله عما
إذا كان بعض أصوله حرا، فإنه لايثبت الولاء لموالي الأم لأن هذا البعض لوكان إنه لونه

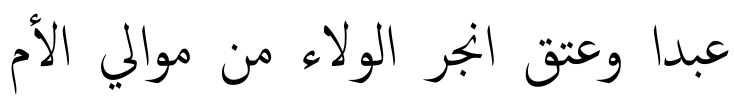

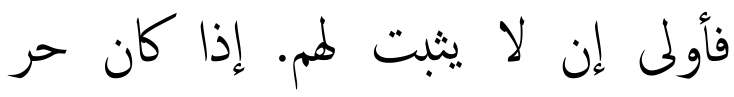
الأصل وإنما انجر الولاء من موالي الأم إلى معتق الأب فيا ذكره لأن ثبوته لمم

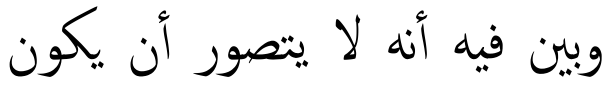

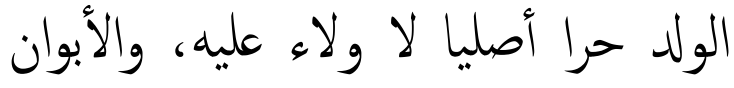
رقيقين إلا في السبي بأن يسترق الأبوان

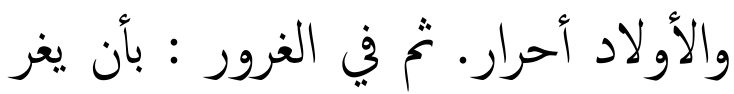

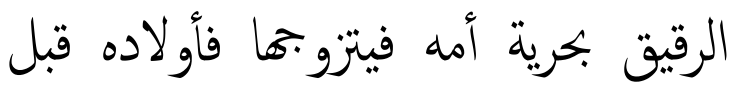

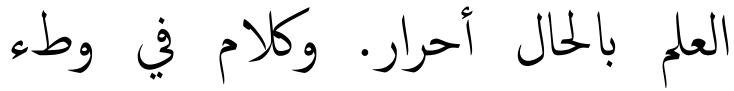
الشبهة : بأن يطء الرقيق أمه الغير على إنى ظن أنها زوجته الحرة فأولاده منها أحرار.

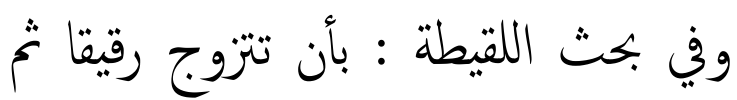
تقر بالرق فأولادها قبل الإقرار أحرار. فلو كان المعتق هو جد الولد بأن الورأن

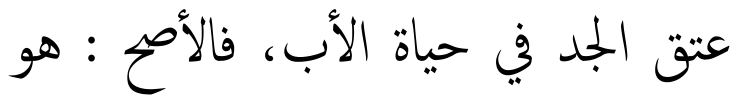
انجرار الولاء من موالي الأم إلى موالي الئ

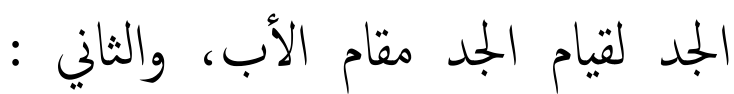

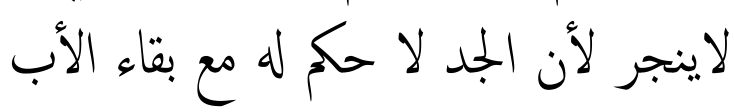

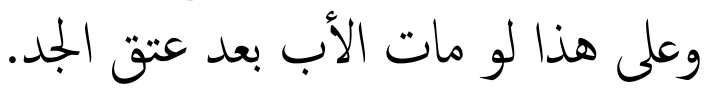


لعبد الله بن محمود بن مودود

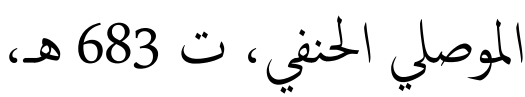
ترجمة و تحقيق : محمد عدنان الدرويش، دار الأرقام. إرواء الغليلفي تخريج أحاديث منار الار السبيل 610/1)، للشيخ محمد إماديت منار ناصر الدين الألباني، المكتب للبن الإسلامي، بيروت، سنة 1405 ه

بداية الجمتهونهاية المقتصد

443/5،لابن رشد، تحقيق

ودراسة: علي محد معوض وعادل أحمد، دار الكتب العلمية، بيروت، الطبعة الأولى سنة المهلة الحنة 1996

- تحقيق المخطوطات بين النظرية والتطبيق، تأليف ودراسة وتحقيق

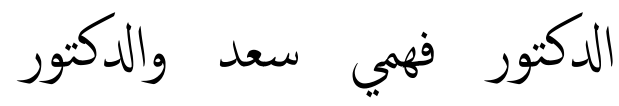
طلال مجذوب ص 4-5، مطبعة عالم الكتب -بيروت لبنان.

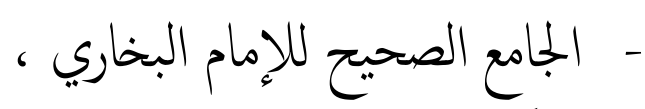

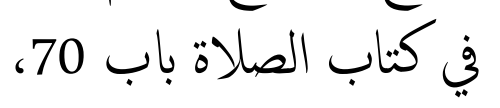
وكتاب الفرائض باب : 19، 20،
22، 23، وكتاب المكانب باب: 5، دار الحديث بالقاهرة. - الحقوق المتعلقة بالتركةبين الفقه

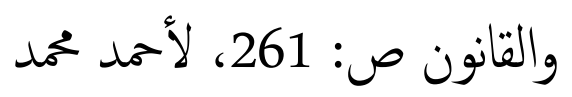
علي، من منشورات وزارة الأوقاف الإسلامية، الأردن، سنة من أرة .) 1982 - سنن ابن ماجه، كناب الفرائض

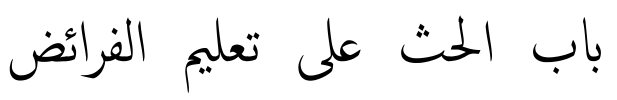
908/2 برقة 2719، دار الحديث بالقاهرة. - مان - - سننابو داود، كتاب الفرائض باب

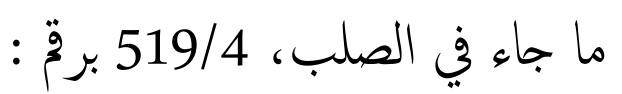
2891، دار الفكر بالقاهرة.

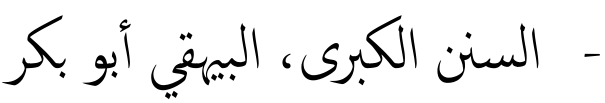

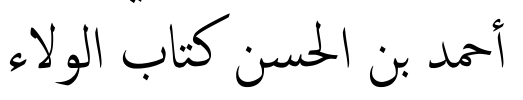
292/10، لأبو بكر أحمد بن الحسين بن علي البيهتي، مطبعة مجلس دائرة المعارف العثانية بحيدر آباد، سنة 1345 هـ].

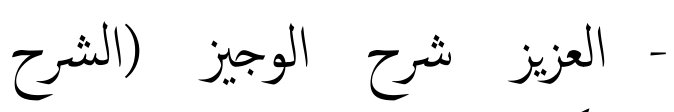
الكبير) للإمام أبي القاسم عبد الكيز

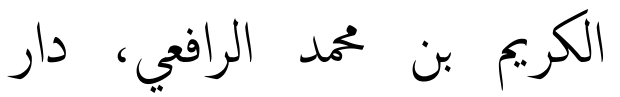
الحديث بالقاهرة، 387/13) 
407 الولاء في الميراث : lin Suryaningsih

- غاية الوصول إلي علم الفصول لشيخ زكريا الأصاري، تحقيق الإني ودراسة : إيئن سورياننجسيه

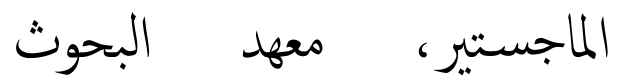
والدراسات التزاثية بجامعة الدول العربية بالقاهرة سنة 2010م. - الفصول المهمة في مواريث الأمة

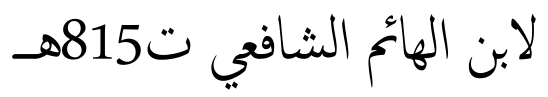

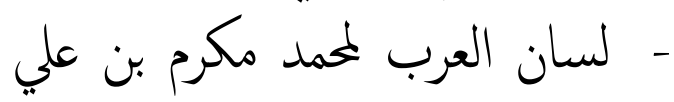
بن منظور، دار الفكر بالقاهرة

$$
\text { 125/4 }
$$

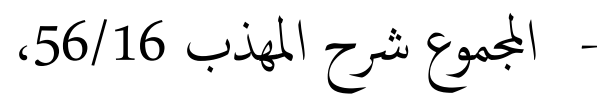
العذب الفائض 19/1، حاشية

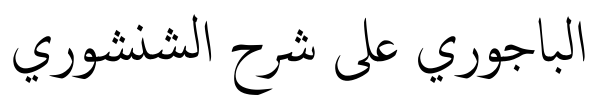

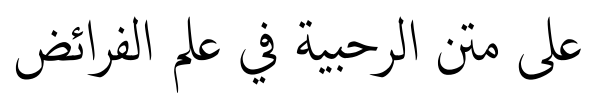

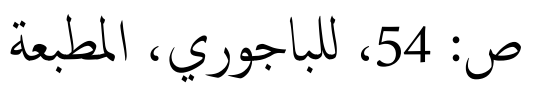
الأزهرية، مصر، الطبعة الثانية

$$
\text { سنة } 1929 \text { هـ). }
$$

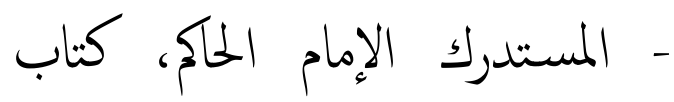
الفرائض باب تعليم الفرائض، دار المائ

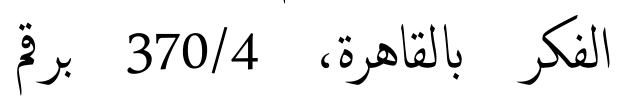

(7953

- نهاية الهداية إلى تخرير الكفاية،

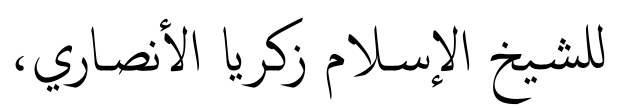

دار العاصـــة بــيروت-لبنــان 103/1

والجامع الصحيح للإمام مسلم، باب إنما الولاء لمن أعتق لإمان 1144-1145/2 ، دابل دار الفكر الغن

بالقاهر 